\title{
Biotechnological Approaches for the Control of Insect Pests in Crop Plants
}

\author{
Jackie Stevens, Kerry Dunse, Jennifer Fox, Shelley Evans and Marilyn Anderson
}

Additional information is available at the end of the chapter

http://dx.doi.org/10.5772/46233

\section{Introduction}

Each year billions of dollars are spent worldwide on insect control in agriculture [1]. Despite this expenditure, up to $40 \%$ of a crop can be lost to insect damage, particularly in developing countries [2]. Some of the most damaging insect species belong to the Lepidoptera, the second largest insect order comprised of moths and butterflies. The larval stage of moths cause major damage to an array of economically valuable crops including cotton, tobacco, tomato, corn, sorghum, lucerne, sunflower, pulses, and wheat [3]. Until recently, broad spectrum chemical insecticides have been the primary control agent for agricultural pests, with about $40 \%$ targeted to the control of lepidopteran insects [4]. Over the years the widespread use of pesticides has led to pesticide resistant insects, a reduction in beneficial insect populations and harmful effects to humans and the environment [5-8]. These problems have led researchers to develop different insect control strategies using both synthetic and natural molecules that are more environmentally friendly.

One such approach has been the use of transgenic plants expressing plant defence molecules. Genetic modification can potentially provide a much larger array of novel insecticidal genes that are otherwise beyond the scope of conventional breeding. The first transgenic plant that expressed an insecticidal gene was produced in 1987. The transgenic tobacco plant produced cowpea trypsin inhibitor at levels of up to $1 \%$ of the soluble protein and had enhanced protection against the lepidopteran pest Heliothis virescens $[9,10]$. The gene encoding the cowpea trypsin inhibitor was subsequently transferred into rice [11] and potato [12,13], but did not provide sustainable insect protection and was thus not commercially viable. Commercial development of insecticidal genes has focused on the Bacillus thuringiensis $(\mathrm{Bt})$ toxins [14,15]. In 1987, genes encoding the Bt endotoxins were also transformed into tobacco and tomato plants [16-18]. Since the commercialisation of biotech crops in 1996, farmers have adopted the technology at such a dramatic rate, that in 2011, 16.7 
million farmers in 29 counties planted 160 million hectares of the biotech crops. This has led to a reduction in chemical pesticide use of 443 million $\mathrm{Kg}$ and an additional financial gain for farmers of US $\$ 78$ billion in the last 15 years [19]. In India alone, Bt-cotton has increased cotton yields by up to $60 \%$, and has reduced insecticide sprays by around half. This in turn has lead to an income increase of up to US \$11.9 billion per annum [19]. The reliance of a worldwide industry on one insect resistance trait has led to real concerns about the development of Bt-resistant insects [20], especially since at least four cases of field based resistance have already been documented [21-23]. This in turn has led to a search for new insecticidal proteins and their encoding genes that have commercial potential for plant protection $[8,24]$. They include $\alpha$-amylase inhibitors $[25,26]$, vegetative insecticidal protein $[27,28]$, chitinases [29] and protease inhibitors [30,31], as well as several other proteins directed to targets in the insect gut (Table 1).

\begin{tabular}{|c|c|c|}
\hline Transgene & Source and Mode of Action & Example of use \\
\hline $\begin{array}{l}\text { Bacillus } \\
\text { thuringiensis (Bt) } \\
\text { endotoxin }\end{array}$ & $\begin{array}{l}\text { See section “The Bacillus } \\
\text { thuringiensis endotoxin" }\end{array}$ & $\begin{array}{l}\text { See section "The Bacillus thuringiensis } \\
\text { endotoxin" }\end{array}$ \\
\hline \multirow{6}{*}{$\begin{array}{l}\text { Vegetative } \\
\text { insecticidal } \\
\text { protein (VIP) }\end{array}$} & \multirow{6}{*}{$\begin{array}{l}\text { VIPs are produced by Bacillus } \\
\text { cereus and Bacillus thuringiensis. } \\
\text { They have similar activity to } \\
\text { endotoxins from Bt. Vip1/Vip2 } \\
\text { are toxic to coleopteran insects } \\
\text { and Vip3 is toxic to } \\
\text { lepidopteran insects [32]. }\end{array}$} & $\begin{array}{l}\text { VIP was highly toxic to Agrotis and } \\
\text { Spodoptera species. VIP induced gut } \\
\text { paralysis, complete lysis of the gut } \\
\text { epithelial cells and resulted in larval } \\
\text { mortality [33]. }\end{array}$ \\
\hline & & $\begin{array}{l}\text { Agrotis ipsilon and Spodoptera frugiperda } \\
\text { larvae suffered gut paralysis, disruption } \\
\text { of midgut epithelial cells and mortality } \\
\text { on Vip3A [34]. }\end{array}$ \\
\hline & & $\begin{array}{l}\text { Vip3A was toxic to A. ipsilon and S. } \\
\text { frugiperda. Larvae of Ostrinia nubilalis and } \\
\text { Danaus plexippus were insensitive [35]. }\end{array}$ \\
\hline & & $\begin{array}{l}\text { Vip3Aa14 was toxic to Spodoptera litura } \\
\text { and Plutella xylostella. Larvae of } \\
\text { Helicoverpa armigera and Pieris brassicae } \\
\text { were insensitive [27]. }\end{array}$ \\
\hline & & $\begin{array}{l}\text { VIP3Ac1 had insecticidal activity against } \\
\text { larvae of S. frugiperda, Helicoverpa zea and } \\
\text { Trichoplusia ni, but low activity against } \\
\text { Bombyx mori and O. nubilalis. The } \\
\text { chimeric protein Vip3AcAa was } \\
\text { insecticidal to O. nubilalis [28]. }\end{array}$ \\
\hline & & $\begin{array}{l}\text { Vip3LB resulted in growth inhibition of } \\
\text { Spodoptera littoralis when incorporated } \\
\text { into a semi solid artificial diet [36]. }\end{array}$ \\
\hline
\end{tabular}




\begin{tabular}{|c|c|c|}
\hline Transgene & Source and Mode of Action & Example of use \\
\hline \multirow{5}{*}{$\begin{array}{l}\text { Biotin binding } \\
\text { proteins } \\
\text { (avidin and } \\
\text { streptavidin) }\end{array}$} & $\begin{array}{l}\text { Biotin is an essential vitamin } \\
\text { for insects. It functions as a } \\
\text { covalently-bound cofactor in } \\
\text { various carboxylases, which } \\
\text { have major roles in } \\
\text { gluconeogenesis, lipogenesis, } \\
\text { amino acid and fatty acid } \\
\text { catabolism, and the citric acid } \\
\text { cycle. }\end{array}$ & $\begin{array}{l}\text { Avidin and streptavidin increased } \\
\text { mortality in four Lepidoptera; Epiphyas } \\
\text { postvittana, Planotortrix octo, Ctenopseustis } \\
\text { obliquana and Phthorimaea operculella when } \\
\text { incorporated into artificial diets [37]. }\end{array}$ \\
\hline & \multirow{4}{*}{$\begin{array}{l}\text { Avidin is a water-soluble } \\
\text { tetrameric glycoprotein from } \\
\text { chicken egg, which binds } \\
\text { strongly to biotin. Streptavidin } \\
\text { is a homologous protein found } \\
\text { in the culture supernatant of } \\
\text { Streptomyces avidinii. }\end{array}$} & $\begin{array}{l}\text { Transgenic plants with leaves expressing } \\
\text { avidin in the vacuole halted growth and } \\
\text { caused mortality in H. armigera and } S . \\
\text { litura larvae [38]. }\end{array}$ \\
\hline & & $\begin{array}{l}\text { Transgenic tobacco plants expressing } \\
\text { either avidin or streptavidin increased } \\
\text { mortality of the potato tuber moth }(P . \\
\text { operculella). Similarly, transgenic apple } \\
\text { expressing either avidin or streptavidin } \\
\text { increased mortality and decreased } \\
\text { growth of the lightbrown apple moth } \\
(\text { E. postvittana) [39]. }\end{array}$ \\
\hline & & $\begin{array}{l}\text { Transgenic tobacco expressing avidin } \\
\text { reduced S. litura larval mass [40]. }\end{array}$ \\
\hline & & $\begin{array}{l}\text { Transgenic tobacco expressing three } \\
\text { variants of biotin binding proteins in the } \\
\text { vacuole increased mortality of } P \text {. } \\
\text { operculella larvae [41]. }\end{array}$ \\
\hline \multirow{3}{*}{$\begin{array}{l}\text { Chitinase } \\
\text { (enzyme) }\end{array}$} & \multirow{3}{*}{$\begin{array}{l}\text { Chitinase catalyses the } \\
\text { hydrolysis of chitin, which is } \\
\text { one of the vital components of } \\
\text { the lining of the digestive tract } \\
\text { in insects and is not present in } \\
\text { plant and higher animals. }\end{array}$} & $\begin{array}{l}\text { Transgenic tobacco plants expressing } M \text {. } \\
\text { sexta chitinase caused a reduction in } \\
\text { survival and growth of } H \text {. virescens, but } \\
\text { not } M . \text { sexta larvae [42]. }\end{array}$ \\
\hline & & $\begin{array}{l}\text { Lacanobia oleracea larvae exposed to diet } \\
\text { containing recombinant L. oleracea } \\
\text { chitinase had a reduction in weight gain } \\
\text { and consumption compared to control- } \\
\text { fed larvae [43]. }\end{array}$ \\
\hline & & $\begin{array}{l}\text { Transgenic rapeseed (Brassica napus) } \\
\text { expressing } M . \text { sexta chitinase and } \\
\text { scorpion insect toxin increased mortality } \\
\text { and reduced growth of Plutella } \\
\text { maculipenis [44]. }\end{array}$ \\
\hline
\end{tabular}




\begin{tabular}{|c|c|c|}
\hline Transgene & Source and Mode of Action & Example of use \\
\hline & & $\begin{array}{l}\text { Oral injection of } B . \text { mori chitinase (Bm- } \\
\text { CHI) caused high mortality in Japanese } \\
\text { pine beetle, Monochamus alternates } \\
\text { (Coleoptera). The peritrophic membrane } \\
\text { chitin was degraded by Bm-CHI, but the } \\
\text { midgut epithelium was not affected [29]. }\end{array}$ \\
\hline \multirow{2}{*}{$\begin{array}{l}\text { Cholesterol } \\
\text { oxidase } \\
\text { (enzyme) }\end{array}$} & \multirow{2}{*}{$\begin{array}{l}\text { Cholesterol oxidase is a } \\
\text { bacterial enzyme that catalyzes } \\
\text { the oxidation of cholesterol and } \\
\text { other 3-hydroxysterols, } \\
\text { resulting in production of the } \\
\text { corresponding 3- } \\
\text { hydroxysterols and hydrogen } \\
\text { peroxide. Functions by } \\
\text { damaging midgut membranes. }\end{array}$} & $\begin{array}{l}\text { Cholesterol oxidase from Streptomyces } \\
\text { caused stunting of } H \text {. virescens, H. zea and } \\
\text { Pectinophora gossypiella when } \\
\text { incorporated into an artificial diet [45]. }\end{array}$ \\
\hline & & $\begin{array}{l}\text { Cholesterol oxidase expressing tobacco } \\
\text { leaves that were incorporated in artificial } \\
\text { diets caused mortality and severe } \\
\text { stunting of neonate Anthonomus grandis } \\
\text { larvae [46]. }\end{array}$ \\
\hline $\begin{array}{l}\text { Lipoxygenases } \\
\text { (enzyme) }\end{array}$ & $\begin{array}{l}\text { Dioxygenase enzymes are } \\
\text { widely distributed in plants and } \\
\text { catalyse the hydroperoxidation } \\
\text { of cis-cis-pentadiene moieties in } \\
\text { unsaturated fatty acids. } \\
\text { Functions by damaging midgut } \\
\text { membranes. }\end{array}$ & $\begin{array}{l}\text { Lipoxygenase from soybean retards the } \\
\text { growth of Manduca sexta when } \\
\text { incorporated into artificial diet [47]. }\end{array}$ \\
\hline $\begin{array}{l}\text { Alpha-amylase } \\
\text { inhibitors }\end{array}$ & $\begin{array}{l}\text { Alpha-amylase inhibitors block } \\
\text { starch digestion. Widespread in } \\
\text { microorganisms, plants and } \\
\text { animals, }[25,26] .\end{array}$ & $\begin{array}{l}\text { Development of pea weevil larvae } \\
\text { (Bruchus pisorum; Coleoptera) was } \\
\text { blocked at an early stage after ingestion } \\
\text { of transgenic peas expressing an alpha- } \\
\text { amylase inhibitor from the common bean } \\
\text { (Phaseolus vulgaris) [48]. }\end{array}$ \\
\hline \multirow{3}{*}{$\begin{array}{l}\text { Alpha-amylase } \\
\text { inhibitors }\end{array}$} & \multirow{3}{*}{$\begin{array}{l}\text { Alpha-amylase inhibitors block } \\
\text { starch digestion. Widespread in } \\
\text { microorganisms, plants and } \\
\text { animals, }[25,26] \text {. }\end{array}$} & $\begin{array}{l}\text { Alpha-amylase inhibitor protects against } \\
\text { predation by certain species of bruchids } \\
\text { (Coleoptera: Bruchidae) and the tomato } \\
\text { moth, L. oleracea (Lepidoptera) [49]. }\end{array}$ \\
\hline & & $\begin{array}{l}\text { Alpha-amylase inhibitor } 1 \text {, from the } \\
\text { common bean (P. vulgaris), provided } \\
\text { complete protection against pea weevil } \\
\text { (B. pisorum; Coleoptera) in transgenic } \\
\text { peas. Whereas alpha-amylase inhibitor } 2 \\
\text { delayed maturation of larvae [50]. }\end{array}$ \\
\hline & & $\begin{array}{l}\text { The alpha-amylase activity in Tecia } \\
\text { solanivora larvae was inhibited by alpha- } \\
\text { amylase inhibitor from amaranth seeds [51] }\end{array}$ \\
\hline
\end{tabular}




\begin{tabular}{|c|c|c|}
\hline Transgene & Source and Mode of Action & Example of use \\
\hline $\begin{array}{l}\text { Protease } \\
\text { inhibitors }\end{array}$ & $\begin{array}{l}\text { See section Protease inhibitors } \\
\text { for the control of insect pests }\end{array}$ & See Table 2 \\
\hline \multirow{7}{*}{ Lectins } & \multirow{7}{*}{$\begin{array}{l}\text { Multivalent carbohydrate- } \\
\text { binding proteins. Some bind to } \\
\text { midgut epithelial cells, } \\
\text { disrupting their function, } \\
\text { causing breakdown of nutrient } \\
\text { transport, and absorption of } \\
\text { potentially harmful substances } \\
\text { [25,52]. }\end{array}$} & $\begin{array}{l}\text { Lectin from soybean seed inhibited larval } \\
\text { growth of } M \text {. sexta [47]. }\end{array}$ \\
\hline & & $\begin{array}{l}\text { Wheatgerm agglutinin was toxic when } \\
\text { fed to O. nubilalis. Formation of the } \\
\text { peritrophic membrane was disrupted in } \\
\text { the anterior midgut microvilli [53]. }\end{array}$ \\
\hline & & $\begin{array}{l}\text { O. nubilalis growth was strongly inhibited } \\
\text { by wheat germ agglutinin (WGA), } \\
\text { whereas } M \text {. sexta was not affected. In } O \text {. } \\
\text { nubilalis larvae, WGA caused } \\
\text { hypersecretion of unorganized } \\
\text { peritrophic membrane in the anterior } \\
\text { midgut lumen, disintegration of } \\
\text { microvilli and cessation of feeding [54] }\end{array}$ \\
\hline & & $\begin{array}{l}\text { The snowdrop lectin (Galanthus nivalis, } \\
\text { agglutinin, GNA) reduced L. oleracea } \\
\text { larval biomass and slowed larval } \\
\text { development when in an artificial diet or } \\
\text { expressed in potato plants [55]. }\end{array}$ \\
\hline & & $\begin{array}{l}\text { Transgenic potato expressing snowdrop } \\
\text { lectin (G. nivalis agglutinin; GNA) } \\
\text { reduced development of L. oleracea larvae. } \\
\text { Transgenic plants were significantly less } \\
\text { damaged [56]. }\end{array}$ \\
\hline & & $\begin{array}{l}\text { Transgenic tobacco plants expressing leaf } \\
\text { (ASAL) and bulb (ASAII) agglutinins } \\
\text { from Allium sativum retarded S. littoralis } \\
\text { larval development and growth [57]. }\end{array}$ \\
\hline & & $\begin{array}{l}\text { The Moringa oleifera lectin (cMoL) } \\
\text { reduced Anagasta kuehniella larval growth } \\
\text { and increased development time and } \\
\text { pupal mortality when incorporated into } \\
\text { an artificial diet [58] }\end{array}$ \\
\hline $\begin{array}{l}\text { Trypsin- } \\
\text { modulating } \\
\text { ostatic factor } \\
\text { (TMOF) }\end{array}$ & $\begin{array}{l}\text { A peptide that blocks trypsin } \\
\text { biosynthesis in mosquitoes } \\
\text { (Aedes aegypti; Diptera [Aea- } \\
\text { TMOF]) and fleshflies } \\
\text { (Sarcophaga; Diptera) [59]. }\end{array}$ & $\begin{array}{l}\text { Injection or oral ingestion of Aea-TMOF } \\
\text { caused inhibition of trypsin biosynthesis } \\
\text { and larval growth in } H \text {. virescens. } \\
\text { Mortality of } H \text {. virescens increased when } \\
\text { fed transgenic tobacco plants expressing } \\
\text { Aea-TMOF [60]. }\end{array}$ \\
\hline
\end{tabular}




\begin{tabular}{|c|c|c|}
\hline Transgene & Source and Mode of Action & Example of use \\
\hline $\begin{array}{l}\text { Isopentenyl- } \\
\text { transferase gene } \\
\text { (ipt) }\end{array}$ & $\begin{array}{l}\text { Microorganism-derived gene } \\
\text { from Agrobacterium tumefaciens. } \\
\text { Codes for a key enzyme in the } \\
\text { cytokinin-biosynthetic pathway. }\end{array}$ & $\begin{array}{l}\text { Ipt expressed in tobacco and tomato } \\
\text { decreased leaf consumption by M. sexta } \\
\text { and reduced survival of the peach potato } \\
\text { aphid, Myzus persicae (Hemiptera) [61]. }\end{array}$ \\
\hline $\begin{array}{l}\text { RNAi } \\
\text { constructs: } \\
\text { 1) Vacuolar } \\
\text { ATPase }\end{array}$ & $\begin{array}{l}\text { Nutrient uptake by midgut } \\
\text { cells is energized by the } \\
\text { electrical difference created by } \\
\text { the K+ pump. The K+ pump } \\
\text { also regulates midgut lumen } \\
\text { pH and determines the } \\
\text { potassium concentration in } \\
\text { blood, epithelial cells and } \\
\text { midgut lumen [62]. The } \\
\text { primary motor for transport is a } \\
\text { vacuolar-type proton ATPase. }\end{array}$ & $\begin{array}{l}\text { Transgenic corn plants expressing } \\
\text { dsRNA of a V-ATPase from Diabrotica } \\
\text { virgifera (western corn rootworm [WCR], } \\
\text { Coleoptera) showed significant reduction } \\
\text { in WCR feeding and plant damage [63]. } \\
\end{array}$ \\
\hline $\begin{array}{l}\text { 2) Cytochrome } \\
\text { P450 } \\
\text { monooxygenase }\end{array}$ & $\begin{array}{l}\text { Cytochrome P450 } \\
\text { monooxygenase permits insects } \\
\text { to tolerate otherwise inhibitory } \\
\text { concentrations of the cotton } \\
\text { metabolite, gossypol. }\end{array}$ & $\begin{array}{l}\text { H. armigera fed on plants expressing } \\
\text { cytochrome P450 dsRNA had retarded } \\
\text { growth. Growth inhibition was more } \\
\text { dramatic in the presence of gossypol [64]. }\end{array}$ \\
\hline \multirow[b]{2}{*}{ 3) Hemolin } & \multirow{2}{*}{$\begin{array}{l}\text { Recognition of microbial } \\
\text { infection is an essential first } \\
\text { step in immunity in insects. } \\
\text { Induction of this protective } \\
\text { effect is associated with up- } \\
\text { regulation of microbial pattern } \\
\text { recognition protein genes such } \\
\text { as hemolin. }\end{array}$} & $\begin{array}{l}\text { Pupae of the giant silkmoth (Hyalophora } \\
\text { cecropia) were injected with hemolin } \\
\text { dsRNA and developed normally into } \\
\text { moths. After mating, no larvae emerged } \\
\text { from the eggs which had malformed } \\
\text { embryos [65]. }\end{array}$ \\
\hline & & $\begin{array}{l}\text { Prior infection of } M . \text { sexta larvae with } \\
\text { non-pathogenic E. coli, elicited effective } \\
\text { immunity against subsequent infection } \\
\text { by the lethal pathogen Photorhabdus } \\
\text { luminescens. Injection of hemolin dsRNA } \\
\text { left the insect more susceptible to } P \text {. } \\
\text { luminescens infection than insects that had } \\
\text { not experienced prior infection with } E \text {. } \\
\text { coli [66]. }\end{array}$ \\
\hline
\end{tabular}

Table 1. Biotechnological approaches for the control of lepidopteran insects with transgenes

\subsection{Helicoverpa species}

Helicoverpa species (Figure 1) are polyphagous pests of at least 181 plant species from 49 families including cotton, corn, soybeans, tobacco and chick-pea [67-69]. They are one of the 
most serious pests in cotton-producing countries like Australia, India and China, causing enormous economic problems [70,71].

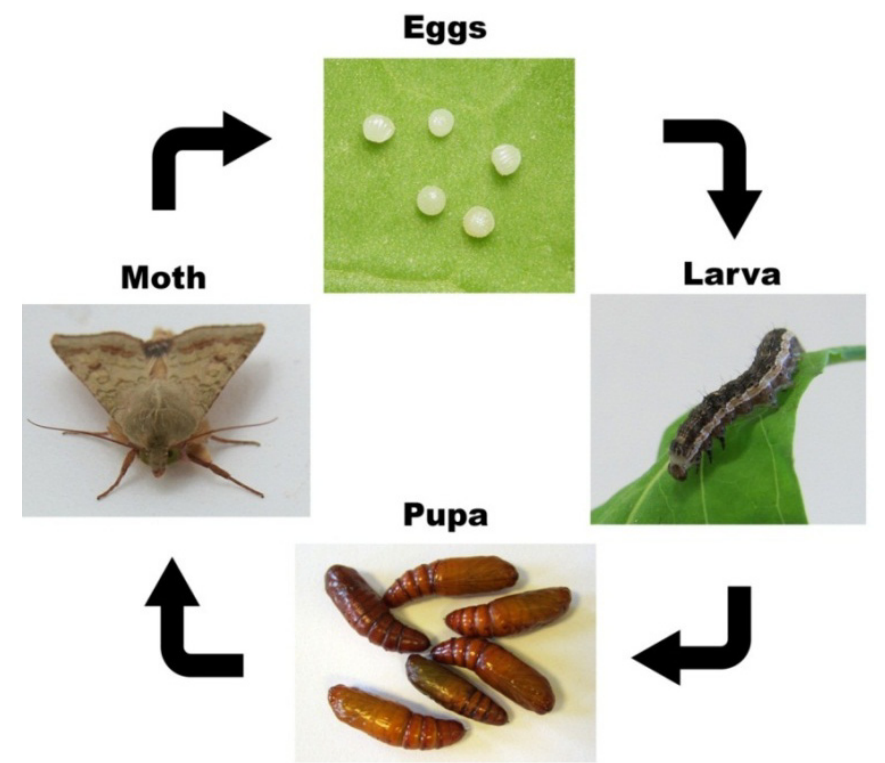

The lepidopteran species, H. armigera, progresses though four stages of development; egg, six larval instars, pupal and adult. The time frame of each of these stages varies with environmental conditions. Over the warmer months, the life cycle can be completed in 30-40 days and each female moth can lay from 500-3000 eggs.

Figure 1. Helicoverpa armigera life cycle

One of the reasons these pests are so damaging is the larva's feeding preference for plant structures that are high in nitrogen, principally reproductive structures and growing points such as cotton buds and bolls, corn ears, tobacco buds, and sorghum heads. Damage to these structures has a direct influence on yield [67]. H. armigera larvae are foliar feeders at the early instar stage and shift to developing seeds or bolls at later stages [72]. H. armigera is a major problem in Australia because it has developed resistance to many of the chemical insecticides that have been used for its control [68,73]. Unlike other lepidopteran species, $H$. armigera larvae don't migrate far from their original host plant, consequently their populations in agricultural areas are exposed to consistent selection pressure, leading to greater resistance to insecticides [5].

In the 1995/96 growing season, transgenic cotton known as Ingard that expressed the Cry1Ac gene became commercially available in Australia [71]. To preserve the susceptibility of lepidopterans to Bt toxins, a conservative resistance management plan was imposed, where planting of Ingard cotton was restricted to $30 \%$ of the cotton production area per farm [71]. The average amount of insecticide used per hectare was $44 \%$ lower on Ingard cotton compared to conventional cotton [71]. In the 2004/05 growing season, Ingard cotton was replaced by Bollgard II, which expressed both the Cry1Ac and Cry2Ab genes [71]. 
Restrictions were not placed on this new variety and Bollgard II cotton comprised around $80 \%$ of the total cotton area planted in Australia during the 2004/05 and 2005/06 seasons [71] and $95 \%$ of the total cotton area in the 2010/2011 season [19]. This reduced the average amount of insecticide used per hectare by $85 \%$ compared to conventional cotton [71]. So far, there have been no reported field failures of Bollgard II due to resistance. However, while alleles that confer resistance to Cry1Ac in H. armigera are rare in the field, alleles that confer resistance to $\mathrm{Cry} 2 \mathrm{Ab}$ are more common.

\section{The use of genetically modified plants for control of lepidopteran insects}

As mentioned previously, insects are responsible for major crop losses worldwide. In addition to direct impacts on yield, insects also reduce yields by making crops more susceptible to disease causing pathogens [8]. Last decade, most control measures focused on the use of chemical pesticides, a curative pest control strategy that was useful for rapid control of certain pest outbreaks. However, excessive and indiscriminate large-scale use of pesticides has led to development of pesticide-resistant insects [74]. Additionally, the longterm and extensive use of synthetic chemicals has led to concerns regarding their impact on food safety, associated human health and the environment [8]. As the use of pesticides for prevention of insect-associated losses cannot be overlooked in agriculture, there is a greater need to develop alternative or additional technologies which would allow a more selective use of pesticides and provide sustainable crop protection [52]. To achieve this objective, it is necessary to enhance the resistance of plants to pests and pathogens through integrated pest management (IPM) programs. They will need to consist of a combination of control strategies including (A) the use of natural biocontrol factors such as pathogens, predators or parasites [75]; (B) various preventive pest control strategies including crop rotation, intercropping, and cultivation of pest-resistant varieties of plants [8] and (C) genetic control via the release of sterile insects and also the use of natural insecticides. The latter includes secondary metabolites [52,76], viruses $[77,78]$ and transgenes.

As the products of most transgenes are ingested by the insect pest and therefore act through the gut, most of the focus has been on transgene encoded proteins that target the insect midgut and/or the peritrophic membrane to disrupt digestion or nutrition [53,54,79-81]. Generally, the detrimental effects on larval and insect growth result from limited assimilation of nutrients [82-85]. Furthermore, any severe delay in growth and development, in a natural setting, lengthens the period in which the larvae are vulnerable to natural predators such as mice, spiders and predaceous insects [30,86,87]. The use of transgenic plants that express insecticidal agents thus reduces the population of insect pests and reduces the usage of chemical insecticides. This extends the useful life of the insecticides and also reduces the ecological damage they may cause [61]. As with any new method of insect control, the impact of transgenic plants on non-target and beneficial insects, particularly pollinators such as honey bees, needs to be assessed [88-90]. Table 1 lists a number of biotechnology approaches tested on lepidopteran insects. Since the discovery that dsRNA 
can silence genes, RNA interference (RNAi) has been developed as an effective tool for regulating gene expression in plants and animals. RNA interference or gene silencing has been used to inhibit virus replication and spread in transgenic plants and has potential to be developed commercially for disease control [91]. The use of RNAi for insect control is less well developed. Insect genes can be down-regulated by injection of dsRNA or by oral administration of high concentrations of exogenously supplied dsRNA as part of an artificial diet, but a much more efficient method of delivering dsRNA is needed before RNAi technology can be used to control pests in the field $[64,65]$. To date, the most successful transgenes for insect control have been the genes encoding insecticidal toxins from the soil bacterium Bacillus thuringiensis.

\subsection{The Bacillus thuringiensis endotoxins}

The use of genes encoding endotoxins from Bacillus thuringiensis is now a well-established technology for producing transgenic plants with enhanced resistance to the larvae of lepidopteran insect pests [92]. Bt cotton was first released for commercial production in the USA in 1996 and subsequently grown in several countries including Argentina, Australia, China, Colombia, Indonesia, Mexico, South Africa, and India [93]. Since then other transgenic crop species producing $\mathrm{Bt}$ toxins have been commercialized including maize, tomato and potato (http://cera-gmc.org). The adoption of Bt crop varieties by farmers has been rapid reflecting the benefits of these crops such as reduced insecticide use, lower production costs and higher yields [94]. Only two Bt crops are grown in Australia (Table 2). In the most recent season (2011/2012) approximately 80\% of the cotton grown in Australia was Bollgard II @ [95].

B. thuringiensis, a Gram-positive soil bacterium, produces a proteinaceous parasporal crystalline inclusion during sporulation [96]. There are two main categories of Bt toxins: Cry and Cyt. These two groups are classified further by a detailed nomenclature system that describes groups Cry1 to Cry55 and Cyt1 to Cyt2 [97-99]. The Cry toxins are divided into three larger families that are not related phylogenetically. The largest Cry family is the three domain family, and genes from this family are present in the majority of commercialised Bt crops [100].

The larvae of insect orders primarily affected by Bt toxins are Lepidoptera (butterflies and moths), Diptera (mosquitoes) and Coleoptera (larval and adult beetles) [101]. However, Bt toxins are not toxic to people, wildlife, or most beneficial insects $[102,103]$ and therefore the opportunities for biological control are great. The effect of Bt toxins on a range of lepidopteran insects has been studied including: Bombyx mori [104], Helicoverpa armigera [105], Heliothis virescens [106,107], Manduca sexta [108,109], Ostrinia nubilalis [110-113], Plutella xylostella [114,115], Sesamia nonagrioides [115], Spodoptera exigua [116], Spodoptera frugiperda [117] and Spodoptera littoralis [118]. The Cry toxins produced in Bt crops generally target lepidopteran pests, although some also target coleopteran pests [100]. The first commercialised Bt crops contained only one Cry toxin, but second generation Bt crops have between two to six different toxins [100]. 
Pesticides - Advances in Chemical and Botanical Pesticides

\begin{tabular}{|l|l|l|l|l|}
\hline \multicolumn{1}{|c|}{ Trade name } & \multicolumn{1}{|c|}{ Crop } & \multicolumn{1}{c|}{ Bt protein } & \multicolumn{1}{c|}{ Company } & \multicolumn{1}{c|}{ Year released } \\
\hline Ingard $\AA$ & cotton & Cry1Ac & Monsanto & 1996 \\
\hline Bollgard II $®$ & cotton & Cry1Ac, Cry2Ab & Monsanto & 2003 \\
\hline
\end{tabular}

This table lists the transgenic crops in Australia producing Bt proteins.

Table 2. Bt crops grown in Australia

\subsection{Mechanism of action}

The Bt toxin mechanism of action is described by two models: The pore formation model and the signal transduction model. The initial steps of both models are the same. Upon ingestion by insects the crystalline inclusion is solubilised in the midgut [119]. Most target insects have a high gut $\mathrm{pH}$ [120] that is crucial for the efficacy of Bt toxins since most Btprotoxins are only soluble above $\mathrm{pH} 9.5$ [121]. The $130 \mathrm{kDa}$ protoxins are activated by insect gut proteases, which typically cleave from both the C- and N-termini resulting in a 43-65 kDa protease-resistant active core [122-125].

The pore formation model has been the accepted mode of action for 20 years and is supported by numerous publications [96,126-128]. In this model the activated toxins bind to the primary receptors in the brush border membrane of the midgut epithelium columnar cells [14]. The major receptors for Cry toxins in lepidopterans are cadherin-like proteins [129-133]. The binding site of Cry toxins varies depending on the structure of the Cry toxin $[105,110]$. Binding to cadherin facilitates further proteolytic cleavage of the toxin and promotes the formation of oligomers $[128,134]$. The toxins then interact with secondary receptors in the midgut larval membrane. These secondary receptors are GPI-anchored proteins; either aminopeptidases or alkaline phosphatases [119,128,131,135]. Following secondary receptor binding, the toxin inserts into the membrane and creates pores [128]. These pores lead to the disruption of membrane integrity and cause an electrolyte imbalance that ultimately leads to death by starvation or septicaemia [136,137]. It is likely that there are more receptors involved in Bt toxicity since insects lacking the cadherin receptor are still killed by modified Bt toxins [138,139].

An alternative model for the Bt toxin mechanism of action proposes that Cry toxins trigger a signalling cascade pathway $[140,141]$. This model differs from the pore formation model in that it does not involve toxin oligomerisation, secondary receptors or the formation of pores in the membrane. Instead, in this model, binding to the cadherin receptor initiates a $\mathrm{Mg}^{+}$ dependent signal cascade pathway that includes a guanine nucleotide-binding protein, adenylyl cyclase, and protein kinase A which ultimately results in cell death.

\subsection{Resistance of lepidopteran insects to $\mathrm{Bt}$ toxins}

More recently there have been reports of field resistance to Bt crops in pink bollworm (Pectinophore gosspiella [142,143]), cotton bollworm (Helicoverpa spp [144-147]), armyworm (Spodoptera frugiperda[22]) and western corn rootworm (Diabrotica virgifera virgifera [148]. Some insects collected from the field have Bt resistance that has been characterized in the 
laboratory. However, there is debate about the relevance of this laboratory resistance in the field [149]. A decrease in field performance of Bt corn against $S$. frugiperda was observed in Puerto Rico [150] and against Busseola fusca in South Africa [23,151]. In southeastern US problems with control of $H$. zea on Bt cotton have also been reported [144-146].

The most common mechanism of resistance is the disruption of binding of Bt toxin to receptors in the midgut membrane. This disruption may be caused either by mutations in the receptor that blocks binding (reviewed in [20]) or changes in expression of the receptors $[152,153]$. Mutations in cadherin genes are responsible for Bt resistance in Heliothis virescens [154], Helicoverpa armigera [155] and Pectinophora gossypiella [156]. Another resistance mechanism associated with an $\mathrm{ABC}$ transporter locus has been reported in three lepidopteran spp (H. virescens, P. xylostella and T. ni [157]). Resistance to Bt in Ostrinia nubialis is due to reduced midgut protease activity resulting in less activation of the protoxins $[111,158,159]$.

\subsection{Management of resistance to Bt crops}

There are two main strategies for management of insect resistance to Bt crops: Refuge and pyramiding. The main approach for delaying evolution of resistance to Bt crops is the refuge strategy [21]. Farmers are mandated to maintain an abundance of host non-Bt crops as a refuge surrounding their Bt crops. The theory behind this strategy is that any Bt resistant larvae that arise on the Bt crops will mate with susceptible individuals from neighbouring non-Bt crops. As long as inheritance of resistance remains recessive the offspring will be susceptible to Bt crops [160-162]. This strategy is then combined with several other mandatory farming practices that include control of volunteer and ratoon plants that arise post-harvest, planting within a defined period of time to restrict the exposure of the Bt crop to the insect pests, restricted use of foliar Bt and the cultivation of crop residues [95]. The other major strategy to combat the evolution of Bt resistance is gene pyramiding. For example, the development of second generation Bt cotton that has at least two Bt toxins such as the Monsanto Bollgard II cotton variety, but up to six Bt toxins [100]. Another resistance management strategy which is still in the research phase of development is the use of insecticidal genes with completely different modes of action such as proteinase inhibitors. The success of combining multiple Bt genes for resistance management is contingent on the individual toxins having different targets to prevent cross resistance developing [163-165]. Binding studies with various Cry toxins have been used to identify toxins with different binding sites in the lepidopteran midguts [105,166,167]. This information can be used to design combinations of Cry toxins that complement each other to delay the development of resistance to Bt crops.

In addition to the resistance management plan for Bollgard cotton outlined above, farmers also use integrated pest management (IPM) systems as a sustainable approach to control all pests. IPM systems deploy a tactical combination of biotechnological, chemical, biological and cultural control methods to avoid pest problems [168]. Some of the major IPM strategies and tools include maintenance of beneficial insect populations, ensuring healthy plant growth, managing weed hosts and monitoring pest populations and plant damage regularly. All these 
additional practices lead to better control of insect populations in general and therefore helps prevent the development of resistance in insect populations to Bt.

\section{Protease inhibitors for the control of insect pests}

Protease inhibitors are one component of a plant's natural defence mechanism against herbivores and pathogens [169]. Plants protect themselves directly by constitutively expressing protease inhibitors [170] and by inducing protease inhibitors in response to mechanical wounding or insect attack $[169,171]$. They may also release volatile compounds after insect damage that function as potent attractants for predators of insect herbivores [172]. The release of volatile compounds after wounding, such as methyl jasmonate also triggers the production of proteinase inhibitors in neighbouring unwounded plants essentially prearming the local population against insect attack [173].

\subsection{Mechanism of action of protease inhibitors on lepidopteran insects}

Protease inhibitors when incorporated into artificial diets or expressed in transgenic plants increase mortality [174] and reduce the growth and development of larvae from many insect pest species including Coleoptera [175,176], Orthoptera [177] and Lepidoptera [178,179](Table 2). The mechanisms by which ingested PIs mediate their effects on insect physiology differs between insect species [180]. Proteinase inhibitors bind to insect digestive proteases, preventing proteolysis which blocks digestion of protein [181]. This effectively starves the larvae of protein and essential amino acids required for insect growth, development and reproduction [182-185]. To compensate for this inhibition, several insect species increase production of proteases to swamp the ingested PIs [186,187]. This in turn can lead to a limitation in bioavailability of essential amino acids for protein synthesis, impairment of growth and development, and potentially death $[182,186]$. The loss of the sulphur-containing amino acids (cysteine and methionine) is critical because the sulfydryl content in trypsin and chymotrypsin is high and reprocurement of the sulphur-containing amino acids is difficult since cysteine and methionine are in relatively low concentrations in the diet, especially if the food source is plant material [186]. Broadway and colleagues confirmed this hypothesis in bioassays with Spodoptera exiqua where the weight-reducing effects obtained with soybean trypsin inhibitor were eliminated when the diets were supplemented with methionine [186].

\subsection{PIs in transgenic plants for plant protection: success and failure}

Several groups have reported enhanced protection of plants against lepidopteran pests after transformation with genes encoding PIs (Table 3). Despite this substantial body of work, defense strategies based on PI expression in plants have not resulted in any commercial application so far $[61,214,215]$. This relates to two distinct problems: (1) the levels of PIexpression in transgenic plants and (2) the pest's capacity to react to PI consumption. Most problems arise from the use of a single transgene producing a PI that targets only one protease or one class of protease in the insect midgut. 


\begin{tabular}{|c|c|c|c|c|c|}
\hline Protease inhibitor & $\begin{array}{c}\text { Protease } \\
\text { family }\end{array}$ & $\begin{array}{l}\text { Proteases } \\
\text { inhibited }\end{array}$ & $\begin{array}{c}\text { Transformed } \\
\text { plant }\end{array}$ & $\begin{array}{c}\text { Insect species } \\
\text { used in } \\
\text { bioassay }\end{array}$ & $\begin{array}{l}\text { Effect of PI on } \\
\text { larval growth }\end{array}$ \\
\hline $\begin{array}{l}\text { Arabidopsis thaliana } \\
\text { serpin } 1 \\
\text { [AtSerpin1] }\end{array}$ & $\begin{array}{l}\text { alpha-1- } \\
\text { peptidase } \\
\text { inhibitor }\end{array}$ & Chymotrypsin & Arabidopsis & $\begin{array}{l}\text { Spodoptera } \\
\text { littoralis }\end{array}$ & $\begin{array}{l}3 \% \text { biomass } \\
\text { reduction after } \\
\text { feeding for } 4 \text { days } \\
{[188]}\end{array}$ \\
\hline \multirow[b]{2}{*}{$\begin{array}{l}\text { Barley trypsin } \\
\text { inhibitor [BTI] }\end{array}$} & \multirow{2}{*}{$\begin{array}{l}\text { Cereal } \\
\text { trypsin } \\
\text { inhibitor }\end{array}$} & \multirow[b]{2}{*}{ Trypsin } & Tobacco & $\begin{array}{l}\text { Spodoptera } \\
\text { exigua }\end{array}$ & $\begin{array}{l}29 \% \text { reduction in } \\
\text { survival [189] }\end{array}$ \\
\hline & & & Wheat & $\begin{array}{l}\text { Sitotroga } \\
\text { cerealella }\end{array}$ & $\begin{array}{l}\text { No effect on } \\
\text { growth or } \\
\text { mortality [190] }\end{array}$ \\
\hline \multirow[t]{2}{*}{$\begin{array}{l}\text { Bovine pancreatic } \\
\text { trypsin inhibitor } \\
\text { [BPTI] }\end{array}$} & \multirow[t]{2}{*}{$\begin{array}{l}\text { Kunitz } \\
\text { (animal) }\end{array}$} & \multirow[t]{2}{*}{$\begin{array}{l}\text { Trypsin, } \\
\text { chymotrypsin, } \\
\text { plasmin, } \\
\text { kallikreins }\end{array}$} & Tobacco & $\begin{array}{l}\text { Spodoptera } \\
\text { exigua }\end{array}$ & $\begin{array}{l}\text { Reduced trypsin } \\
\text { activity; induced } \\
\text { leucine } \\
\text { aminopeptidase } \\
\text { and } \\
\text { carboxypeptidase } \\
\text { A activities; } \\
\text { chymotrypsin, } \\
\text { elastase, and } \\
\text { carboxypeptidase } \\
\text { B proteases not } \\
\text { affected [190] }\end{array}$ \\
\hline & & & Sugarcane & $\begin{array}{l}\text { Scirpophaga } \\
\text { excerptalis }\end{array}$ & $\begin{array}{l}\text { Significant } \\
\text { reduction in } \\
\text { weight [191] }\end{array}$ \\
\hline $\begin{array}{l}\text { Bovine spleen } \\
\text { trypsin inhibitor } \\
\text { [SI] }\end{array}$ & $\begin{array}{l}\text { Kunitz } \\
\text { (animal) }\end{array}$ & $\begin{array}{l}\text { Trypsin, } \\
\text { chymotrypsin }\end{array}$ & Tobacco & $\begin{array}{l}\text { Helicoverpa } \\
\text { armigera }\end{array}$ & $\begin{array}{l}\text { Reduced survival } \\
\text { and growth [192] }\end{array}$ \\
\hline \multirow{6}{*}{$\begin{array}{l}\text { Cowpea trypsin } \\
\text { inhibitor [CpTI] }\end{array}$} & \multirow{6}{*}{\begin{tabular}{|l} 
Bowman- \\
Birk
\end{tabular}} & \multirow{6}{*}{ Trypsin } & Tobacco & $\begin{array}{l}\text { Heliothis } \\
\text { virescens }\end{array}$ & $\begin{array}{l}\text { Increased } \\
\text { mortality [9] }\end{array}$ \\
\hline & & & Tobacco & Helicoverpa zea & $\begin{array}{l}\text { Increased } \\
\text { mortality [193] }\end{array}$ \\
\hline & & & Rice & \begin{tabular}{|l|} 
Chilo \\
suppressalis- \\
Sesamia inferens
\end{tabular} & $\begin{array}{l}\text { Growth not } \\
\text { monitored [11] }\end{array}$ \\
\hline & & & Potato & \begin{tabular}{|l|} 
Lacanobia \\
oleracea
\end{tabular} & $\begin{array}{l}45 \% \text { biomass } \\
\text { reduction [13] }\end{array}$ \\
\hline & & & Tobacco & Spodoptera litura & $\begin{array}{l}50 \% \text { biomass } \\
\text { reduction }[194]\end{array}$ \\
\hline & & & Potato & $\begin{array}{l}\text { Lacanobia } \\
\text { oleracea }\end{array}$ & $\begin{array}{l}\text { Decreased weight } \\
\text { and delayed } \\
\text { development [12] }\end{array}$ \\
\hline $\begin{array}{l}\text { Giant taro } \\
\text { proteinase inhibitor } \\
\text { [GTPI] }\end{array}$ & $\begin{array}{l}\text { Kunitz } \\
\text { (plant) }\end{array}$ & $\begin{array}{l}\text { Trypsin, } \\
\text { chymotrypsin }\end{array}$ & Tobacco & $\begin{array}{l}\text { Helicoverpa } \\
\text { armigera }\end{array}$ & $\begin{array}{l}\text { Decreased growth, } \\
\text { no increase in } \\
\text { mortality [195] }\end{array}$ \\
\hline
\end{tabular}




\begin{tabular}{|c|c|c|c|c|c|}
\hline Protease inhibitor & $\begin{array}{c}\text { Protease } \\
\text { family }\end{array}$ & $\begin{array}{l}\text { Proteases } \\
\text { inhibited }\end{array}$ & $\begin{array}{c}\text { Transformed } \\
\text { plant }\end{array}$ & $\begin{array}{c}\text { Insect species } \\
\text { used in } \\
\text { bioassay }\end{array}$ & $\begin{array}{l}\text { Effect of PI on } \\
\text { larval growth }\end{array}$ \\
\hline \multirow{4}{*}{$\begin{array}{l}\text { Mustard trypsin } \\
\text { inhibitor } 2 \\
\text { [MTI-2] }\end{array}$} & \multirow{4}{*}{$\begin{array}{l}\text { Brassicaceae } \\
\text { proteinase } \\
\text { inhibitor }\end{array}$} & \multirow{4}{*}{$\begin{array}{l}\text { Trypsin, } \\
\text { chymotrypsin }\end{array}$} & & $\begin{array}{l}\text { Spodoptera } \\
\text { littoralis }\end{array}$ & $\begin{array}{l}\text { Increased } \\
\text { mortality; } \\
\text { surviving larvae } \\
\text { up to } 39 \% \text { smaller } \\
\text { after } 10 \text { days [187] }\end{array}$ \\
\hline & & & $\begin{array}{l}\text { Tobacco, } \\
\text { Arabidopsis and } \\
\text { oilseed rape }\end{array}$ & $\begin{array}{l}\text { Mamestra } \\
\text { brassicae, } \\
\text { Plutella } \\
\text { xylostella, } \\
\text { Spodoptera } \\
\text { littoralis }\end{array}$ & $\begin{array}{l}\text { P. xylostella: } 100 \% \\
\text { mortality on } \\
\text { Arabidopsis; high } \\
\text { mortality \& } \\
\text { delayed } \\
\text { development on } \\
\text { oilseed rape. } M \text {. } \\
\text { brassicae: increased } \\
\text { mortality \& weight } \\
\text { of survivors on } \\
\text { Arabidopsis and } \\
\text { tobacco, no effect } \\
\text { on oilseed rape. S. } \\
\text { littoralis: delay in } \\
\text { development on } \\
\text { oilseed rape [178]. }\end{array}$ \\
\hline & & & Tobacco & $\begin{array}{l}\text { Spodoptera } \\
\text { littoralis }\end{array}$ & $\begin{array}{l}\text { No effect on } \\
\text { growth; reduction } \\
\text { in fertility [196] }\end{array}$ \\
\hline & & & Oilseed rape & $\begin{array}{l}\text { Plutella } \\
\text { xylostella }\end{array}$ & $\begin{array}{l}\text { Reduction in } \\
\text { survival and } \\
\text { weight [30] }\end{array}$ \\
\hline \multirow{4}{*}{$\begin{array}{l}\text { Nicotiana alata } \\
\text { protease inhibitor } \\
{[\mathrm{NaPI}]}\end{array}$} & \multirow{4}{*}{$\begin{array}{l}\text { Proteinase } \\
\text { inhibitor II }\end{array}$} & \multirow{4}{*}{$\begin{array}{l}\text { Trypsin, } \\
\text { chymotrypsin }\end{array}$} & Tobacco & $\begin{array}{l}\text { Helicoverpa } \\
\text { punctigera }\end{array}$ & $\begin{array}{l}\text { Decreased weight; } \\
\text { increased } \\
\text { mortality [197] }\end{array}$ \\
\hline & & & $\begin{array}{l}\text { Tobacco and } \\
\text { peas }\end{array}$ & $\begin{array}{l}\text { Helicoverpa } \\
\text { armigera }\end{array}$ & $\begin{array}{l}\text { Increased } \\
\text { mortality; delayed } \\
\text { growth [198] }\end{array}$ \\
\hline & & & $\begin{array}{l}\text { ‘Royal Gala’ } \\
\text { apple }\end{array}$ & $\begin{array}{l}\text { Epiphyas } \\
\text { postvittana }\end{array}$ & $\begin{array}{l}\text { Larval and pupal } \\
\text { weights reduced; } \\
\text { developmental } \\
\text { abnormalities [31] }\end{array}$ \\
\hline & & & Cotton & $\begin{array}{l}\text { Helicoverpa } \\
\text { armigera }\end{array}$ & $\begin{array}{l}\text { A higher number } \\
\text { of cotton bolls } \\
\text { were recorded in } \\
\text { plants expressing } \\
\text { NaPI and a PotI } \\
\text { inhibitor from } \\
\text { potato, StPin1A } \\
\text { [199]. }\end{array}$ \\
\hline
\end{tabular}




\begin{tabular}{|c|c|c|c|c|c|}
\hline Protease inhibitor & $\begin{array}{c}\text { Protease } \\
\text { family }\end{array}$ & $\begin{array}{l}\text { Proteases } \\
\text { inhibited }\end{array}$ & $\begin{array}{c}\text { Transformed } \\
\text { plant }\end{array}$ & $\begin{array}{c}\text { Insect species } \\
\text { used in } \\
\text { bioassay } \\
\end{array}$ & $\begin{array}{l}\text { Effect of PI on } \\
\text { larval growth }\end{array}$ \\
\hline \multirow{6}{*}{$\begin{array}{l}\text { Potato inhibitor II } \\
\text { [Pin II, } \\
\text { PPI- II, } \\
\text { Pot II, } \\
\text { PI-II] }\end{array}$} & \multirow{6}{*}{$\begin{array}{l}\text { Proteinase } \\
\text { inhibitor II }\end{array}$} & \multirow{6}{*}{$\begin{array}{l}\text { Trypsin, } \\
\text { chymotrypsin, } \\
\text { oryzin, } \\
\text { subtilisin, } \\
\text { elastase }\end{array}$} & Tobacco & Manduca sexta & $\begin{array}{l}\text { Growth retarded } \\
{[200]}\end{array}$ \\
\hline & & & Tobacco & \begin{tabular}{|l} 
Chrysodeixis \\
eriosoma, \\
Spodoptera \\
litura, \\
Thysanoplusia \\
orichalcea
\end{tabular} & $\begin{array}{l}\text { C. eriosoma larvae } \\
\text { grew slower; } S \text {. } \\
\text { litura and T. } \\
\text { orichalcea growth } \\
\text { either unaffected } \\
\text { or enhanced [201] }\end{array}$ \\
\hline & & & Tobacco & $\begin{array}{l}\text { Spodoptera } \\
\text { exigua }\end{array}$ & $\begin{array}{l}\text { Growth not } \\
\text { affected [202] }\end{array}$ \\
\hline & & & Rice & Sesamia inferens & $\begin{array}{l}\text { Decreased weight } \\
{[74]}\end{array}$ \\
\hline & & & Brassica napus & $\mid \begin{array}{l}\text { Plutella } \\
\text { xylostella }\end{array}$ & $\begin{array}{l}\text { Lowered growth } \\
\text { rates however } \\
\text { more plant tissue } \\
\text { consumed [203] }\end{array}$ \\
\hline & & & Tomato & $\begin{array}{l}\text { Heliothis } \\
\text { obsoleta }\end{array}$ & \begin{tabular}{|l} 
Increased \\
mortality and \\
decreased weight \\
on homozygous \\
plants expressing \\
PI-II and potato \\
carboxypeptidase \\
inhibitor (PCI), \\
opposite effect on \\
hemizygous plants \\
{$[204]$} \\
\end{tabular} \\
\hline $\begin{array}{l}\text { Solanum americanum } \\
\text { proteinase inhibitor } \\
\text { [SaPIN2a] }\end{array}$ & $\begin{array}{l}\text { Proteinase } \\
\text { inhibitor II }\end{array}$ & $\begin{array}{l}\text { Trypsin, } \\
\text { chymotrypsin }\end{array}$ & Tobacco & \begin{tabular}{|} 
Helicoverpa \\
armigera, \\
Spodoptera litura
\end{tabular} & $\begin{array}{l}\text { Reduction in larval } \\
\text { weight and } \\
\text { pupation rate [205] }\end{array}$ \\
\hline \multirow{4}{*}{$\begin{array}{l}\text { Soybean Kunitz } \\
\text { trypsin inhibitor } \\
{[\text { SBTI, SKTI] }}\end{array}$} & \multirow{4}{*}{$\begin{array}{l}\text { Kunitz } \\
\text { (plant) }\end{array}$} & \multirow{4}{*}{$\begin{array}{l}\text { Trypsin, } \\
\text { chymotrypsin, } \\
\text { kallikrein, } \\
\text { plasmin }\end{array}$} & Poplar & \begin{tabular}{|l} 
Clostera \\
anastomosis, \\
Lymantria dispar
\end{tabular} & $\begin{array}{l}\text { Mortality and } \\
\text { growth not } \\
\text { significantly } \\
\text { affected [206] }\end{array}$ \\
\hline & & & Potato & $\begin{array}{l}\text { Lacanobia } \\
\text { oleracea }\end{array}$ & $\begin{array}{l}\text { Survival and } \\
\text { growth decreased } \\
\text { by } 33 \% \text { and } 40 \% \\
\text { respectively after } \\
21 \text { days [174] }\end{array}$ \\
\hline & & & Tobacco & Spodoptera litura & $\begin{array}{l}\text { Increased } \\
\text { mortality and } \\
\text { delayed } \\
\text { development [207] }\end{array}$ \\
\hline & & & Tobacco & $\begin{array}{l}\text { Helicoverpa } \\
\text { armigera }\end{array}$ & $\begin{array}{l}\text { Development } \\
\text { unaffected [208] }\end{array}$ \\
\hline
\end{tabular}




\begin{tabular}{|c|c|c|c|c|c|}
\hline Protease inhibitor & $\begin{array}{l}\text { Protease } \\
\text { family }\end{array}$ & $\begin{array}{l}\text { Proteases } \\
\text { inhibited }\end{array}$ & $\begin{array}{l}\text { Transformed } \\
\text { plant }\end{array}$ & $\begin{array}{c}\text { Insect species } \\
\text { used in } \\
\text { bioassay }\end{array}$ & $\begin{array}{l}\text { Effect of PI on } \\
\text { larval growth }\end{array}$ \\
\hline & & & $\begin{array}{l}\text { Tobacco and } \\
\text { potato }\end{array}$ & $\begin{array}{l}\text { Spodoptera } \\
\text { littoralis }\end{array}$ & $\begin{array}{l}\text { High mortality on } \\
\text { tobacco and up to } \\
50 \% \text { weight } \\
\text { reduction on } \\
\text { potato [209] }\end{array}$ \\
\hline & & & Sugarcane & $\begin{array}{l}\text { Diatraea } \\
\text { saccharalis }\end{array}$ & $\begin{array}{l}\text { Increased } \\
\text { mortality; retarded } \\
\text { growth [210] }\end{array}$ \\
\hline $\begin{array}{l}\text { Soybean Bowman- } \\
\text { Birk trypsin } \\
\text { inhibitor } \\
\text { [SBBI] }\end{array}$ & $\begin{array}{l}\text { Bowman- } \\
\text { Birk }\end{array}$ & $\begin{array}{l}\text { Trypsin, } \\
\text { chymotrypsin }\end{array}$ & Sugarcane & $\begin{array}{l}\text { Diatraea } \\
\text { saccharalis }\end{array}$ & $\begin{array}{l}\text { Growth severely } \\
\text { retarded [210] }\end{array}$ \\
\hline \multirow{4}{*}{$\begin{array}{l}\text { Sweet potato } \\
\text { trypsin inhibitor } \\
\text { [SWTI, } \\
\text { Sporamin] }\end{array}$} & \multirow{4}{*}{$\begin{array}{l}\text { Kunitz } \\
\text { (plant) }\end{array}$} & \multirow{4}{*}{ Trypsin } & Cauliflower & \begin{tabular}{|l|} 
Plutella \\
xylostella, \\
Spodoptera litura
\end{tabular} & $\begin{array}{l}\text { Increased } \\
\text { mortality [42] }\end{array}$ \\
\hline & & & Tobacco & Spodoptera litura & $\begin{array}{l}\text { Growth and } \\
\text { survival severely } \\
\text { retarded [211] }\end{array}$ \\
\hline & & & Tobacco & $\begin{array}{l}\text { Helicoverpa } \\
\text { armigera }\end{array}$ & $\begin{array}{l}\text { Increased } \\
\text { mortality and } \\
\text { delayed growth } \\
\text { and development } \\
\text { in larvae on plants } \\
\text { expressing } \\
\text { sporamin and a } \\
\text { phytocystatin from } \\
\text { taro, CeCPI [212] }\end{array}$ \\
\hline & & & Brassica & $\begin{array}{l}\text { Plutella } \\
\text { xylostella }\end{array}$ & $\begin{array}{l}\text { Survival rate and } \\
\text { body mass was } \\
\text { significantly lower } \\
\text { in larvae fed plants } \\
\text { expressing } \\
\text { sporamin and } \\
\text { chitinase [213] }\end{array}$ \\
\hline $\begin{array}{l}\text { Tomato inhibitor I } \\
\text { [Tom1] }\end{array}$ & $\begin{array}{l}\text { Proteinase } \\
\text { inhibitor I }\end{array}$ & $\begin{array}{l}\text { Chymotrypsin } \\
\text { subtilisin, } \\
\text { trypsin }\end{array}$ & Tobacco & Manduca sexta & $\begin{array}{l}\text { Little effect on } \\
\text { growth [200] }\end{array}$ \\
\hline $\begin{array}{l}\text { Tomato inhibitor II } \\
\text { [TPI-II] }\end{array}$ & $\begin{array}{l}\text { Proteinase } \\
\text { inhibitor II }\end{array}$ & $\begin{array}{l}\text { Chymotrypsin } \\
\text { trypsin, } \\
\text { subtilisin }\end{array}$ & Tobacco & Manduca sexta & $\begin{array}{l}\text { Growth retarded } \\
{[200]}\end{array}$ \\
\hline
\end{tabular}

This table lists plant and non-plant serine protease inhibitors expressed in transgenic plants that have been tested in bioassays with lepidopteran larvae. The major enzymes targeted by each PI are given, however other enzymes may be weakly inhibited or have not been tested.

Table 3. Serine protease inhibitors that have been tested for their effect on growth and development of lepidopteran larvae 
The first problem of inadequate levels of PI expression is best exemplified by studies with $P$. xylostella, the diamondback moth. When larvae of the diamondback moth consumed transgenic plants expressing the chymotrypsin and trypsin specific potato type II proteinase inhibitor, Pot II, they suffered lower growth rates. However, this did not confer an advantage to the plants because the larvae consumed more tissue to compensate for their decrease in metabolism $[13,203]$. As a result, the insects maintained population growth rates similar to those of larvae on non-transgenic plants. Growth enhancement has been reported after PI ingestion in insects from a number of orders [201,216]. Larvae that consumed tobacco leaves expressing low levels of mustard trypsin inhibitor 2 (MTI-2) developed faster, had an increased mean weight and caused more damage to leaves compared to control larvae on non-transgenic tobacco [187]. The increase in leaf surface consumption observed with plants expressing low levels of MTI-2 may have resulted from a decrease in available protein due to the presence of MTI-2 and/or to an increase in gut proteolytic capacity induced by PI consumption [187].

The second problem, the pest's capacity to react to PI consumption, is exemplified by the observation that several PIs that are potent inhibitors of insect proteases in vitro fail to produce any deleterious effect when fed to larvae [187]. Several mechanisms have been reported for this lack of effect (Figure 2). For example, the complement of proteolytic enzymes in the insect midgut can be altered after PI ingestion [183,214,217]. This could involve a switch to enzymes of different substrate specificity, but the same mechanistic class. For example, production of a chymotrypsin-like enzyme rather than a trypsin-like protease [195,218]. Another mechanism used to detoxify the PIs is degradation via endogenous proteases within the insect midgut [214,219]. Insects that feed regularly on a particular host plant are generally not affected by the PIs produced by the host. For example the PIs from chickpea, a host plant for H. armigera, are rapidly degraded by the $H$. armigera gut proteases $[219,220]$. Similarly, single domain cystatins from potato multicystatin are degraded when fed to larvae of Diabrotica spp (Coleoptera). Sometimes non-host PIs are also rapidly degraded. Human stefin A, a potent inhibitor of human cysteine proteases, was degraded by cystatin-insensitive proteases in the gut of Colorado potato beetle (Leptinotarsa decemlineata) and black vine weevil (Otiorynchus sulcatus) [221]. Another anti-PI mechanism is the production of midgut inhibitor-resistant serine proteases [182,222-224]. Some insect larvae adapt to the presence of PIs by replacing the inhibited enzymes with other PI-resistant proteases and can exhibit increased ingestion rates and faster development than larvae fed on control diets lacking PIs [202,204,225,226]. Some classic examples of this phenomenon are as follows. Soybean Kunitz trypsin inhibitor (SKTI) is normally an effective inhibitor of protease activity in gut extracts from $H$. armigera larvae, this insect is not seriously affected by ingestion of this PI because it responds to chronic ingestion of SKTI by increasing activity of an SKTI-resistant trypsin [227]. Similarly, growth and development of S. exigua larvae was not impacted when fed leaves from tobacco plants transformed with the chymotrypsin/trypsin specific potato proteinase inhibitor II (Pot II) [202]. Analysis of the trypsin activity in the gut of these insects demonstrated that only $18 \%$ of the trypsin activity of insects reared on these 
transgenic plants was inhibited by Pot II, whereas $78 \%$ of the trypsin activity in the gut of insects reared on control plants was Pot II-inhibitable [202]. The larvae had compensated for the loss of the PI-inhibitable trypsin by a 2.5-fold induction of new activity that was resistant to inhibition by Pot II [202]. Another observation of induction of PI-resistant enzymes was made by Markwick and coworkers who reported that the trypsin in three species of leaf rollers (Tortricidae) that had fed on diets containing SKTI was less inhibited by bovine pancreatic trypsin inhibitor (BPTI) compared to the trypsin in control larvae [228]. These responses have been reported for lepidopteran species that have ingested PIs in native plants, transgenic plants, and artificial diets [195,229]. In summary, potent inhibition of an insect digestive enzyme in vitro by a particular PI is not a good prediction that the PI will be useful when expressed as a transgene for crop protection. That is, expression and regulation of midgut serine proteases in herbivorous insects is tightly regulated and is heavily influenced by the levels and the nature of ingested PIs [230,231]. The mechanism by which changes in protease levels and protease isoforms is regulated in response to PI ingestion is still unknown for phytophagous insects. An overview of the effects of PIs on insects is presented in Figure 2.

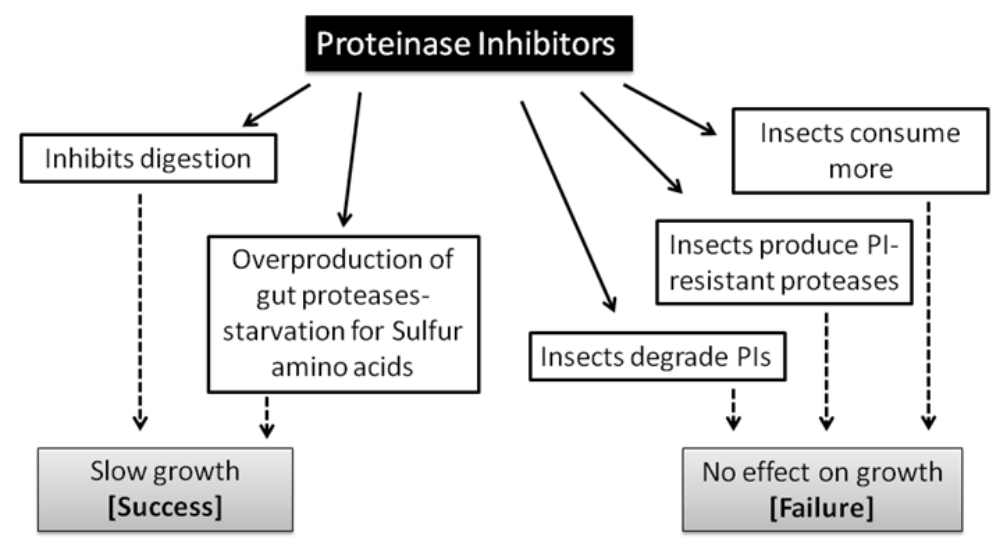

Figure 2. Outline of the various effects of ingested PIs on insect pests leading to success or failure in plant protection

\subsection{Proteinase inhibitors from Nicotiana alata as defence molecules against insect pests}

Female reproductive tissues and wounded leaves of the ornamental tobacco, Nicotiana alata amass high levels of serine proteinase inhibitors for protection against insect pests and pathogens [232]. These serine proteinase inhibitors (NaPI) belong to the Potato type II family (Merops family I20) which have only been described in the Solanaceae. The NaPI precurser protein (NaProPI; $43 \mathrm{kDa}$ ), is composed of an ER signal peptide (29 amino acids), six repeated domains each with a potential PI-reactive site, and a 25 residue C-terminal domain that is essential for vacuolar targeting (VTS) [232-234] ( Figure 3). 


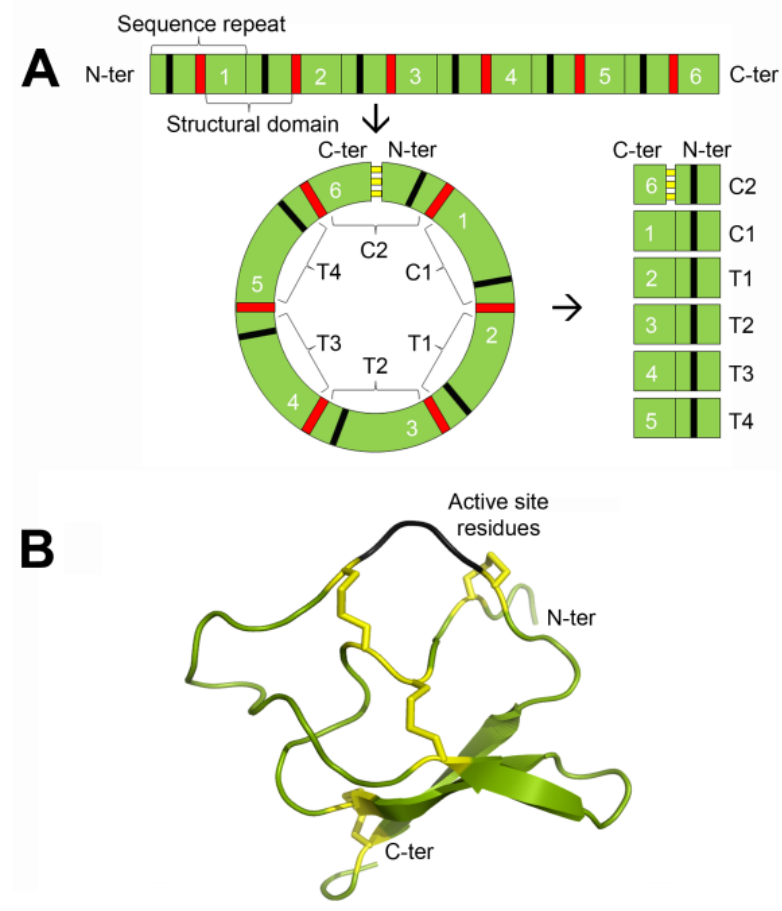

(A) The NaPI precursor protein, shown as a linear gene product, forms a circular 'bracelet' structure that is 'clasped' by three disulphide bonds (yellow) between the N- and C-terminal repeats. Each repeat (labeled 1-6) contains a proteasereactive site (black), which is specific for either chymotrypsin (C1 and C2) or trypsin (T1-4). The six linker regions (red), with sequence EEKKN, are cleaved to release the six active inhibitor domains. The N-terminal signal sequence and the C-terminal vacuolar targeting signal have been omitted for clarity. Figure adapted from Scanlon et al. [235]. (B) Ribbon view of T1 showing the major secondary structural element, a triple stranded $\beta$-sheet (green) and the cysteines involved in disulfide bonds (yellow). The reactive site residues (black) are positioned between two cysteines that anchor the reactive loop to the central coil [236]. The other five inhibitors have the same structure [236-238].

Figure 3. Diagrammatic representation of the domain organisation of NaProPI and the structure of the T1 inhibitor domain

Processing of NaProPI in the secretory pathway removes the ER signal peptide and VTS, and releases six PIs [232,239]. Processing of the six repeat NaProPI occurs at sites located within, rather than between, these repeated regions [232,239]. Complete removal of the linker sequence (Glu-Glu-Lys-Lys-Asn) contained within each repeated region [239], generates five contiguous inhibitors, a chymotrypsin inhibitor (C1) and four trypsin inhibitors (T1-T4), and two flanking peptides from the $\mathrm{N}$ - and C-termini. The flanking peptides form a novel two-chain chymotrypsin inhibitor (C2) that can only be formed if NaPI adopts a circular structure (Figure 3; [240]). The peptides have very similar amino acid sequences [239]. The three-dimensional structures of C1, C2, T1, T2, T3 and T4 have been determined by NMR spectroscopy $[234,236,240]$. A triple stranded $\beta$-sheet is the dominant secondary structural feature; several $\beta$-turns and a short region $\alpha$-helix are also present (Figure 3B; [238]). The reactive site is located on an exposed loop which has a higher degree 
of mobility than other regions of the protein (Figure 3B). This is a common feature of PIs and is thought to allow the inhibitor to adapt to slightly different enzymes [239].

Atkinson and colleagues suggested NaPIs may be involved in deterring insects from feeding on stigmas or in protecting the stigma from pathogen invasion since the related type-II PIs from potato and tomato are effective against proteases of fungal, bacterial and insect origin $[232,241]$. The PIs from $N$. alata inhibit the digestive gut proteases from five insect orders in vitro and display significant inhibitory activity against the midgut proteases of H. punctigera and T. commodus [197,198]. Significant mortality was recorded when H. punctigera larvae were fed transgenic tobacco [197] or transgenic peas [198] expressing the NaPI precursor. More recently, the response of Helicoverpa larvae to ingestion of $\mathrm{NaPI}$ has been more thoroughly characterized. Following ingestion of NaPI, all surviving Helicoverpa punctigera larvae produced high levels of a chymotrypsin that was resistant to inhibition by NaPI [199]. However this NaPI-resistant chymotrypsin was strongly inhibited by a potato type 1 inhibitor which is also produced by solanaceous plants, but belongs to a different class of serine proteinase inhibitors. When presented to $H$. armigera larvae in an artificial diet the combination of $\mathrm{NaPI}$ and the potato type I inhibitor had a much more dramatic effect on growth and development of the larvae compared to either of the inhibitors alone (Figure 4).

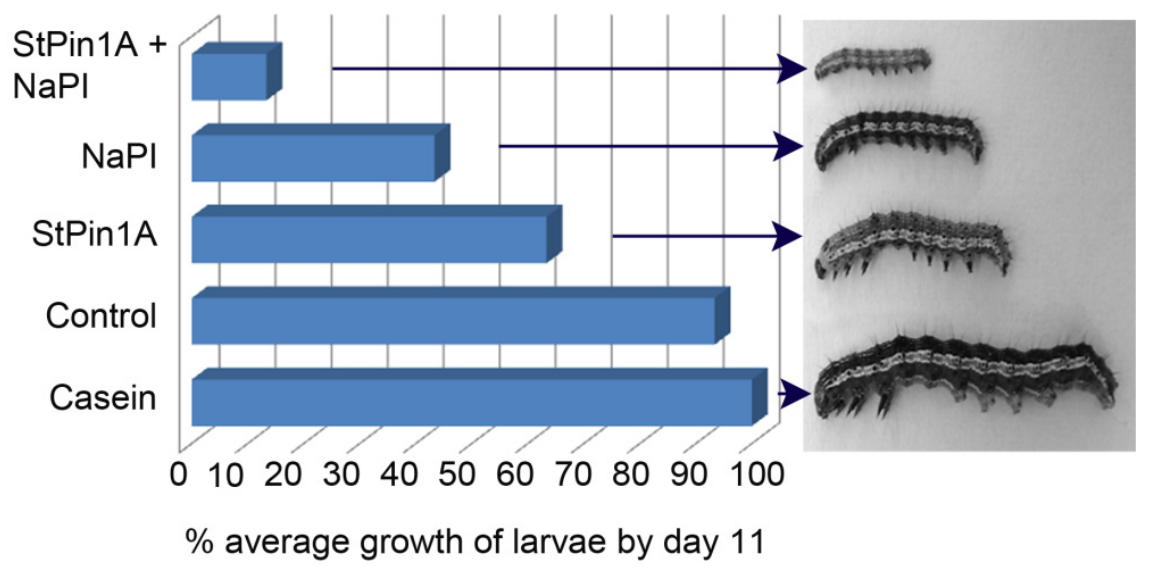

Neonates were transferred to cotton-leaf based artificial diets containing $0.3 \%$ of PIs (NaPI, StPin1A) and growth (mg) measured every $2^{\text {nd }}$ day until day 11 . Day 11 , the $\%$ average weights compared to casein control are shown with representative larvae from each treatment (adapted from [199])

Figure 4. Percentage of Helicoverpa larval growth on day 11.

This laboratory result was then translated to transgenic plants in the field. Transgenic cotton plants expressing both PI classes, NaPI and StPin1A performed better than transgenic cotton plants expressing either PI alone. The improved performance of the transgenic cotton plants with both PIs was measured by an increase in cotton boll number per plant and increased yield of lint at the end of the cotton growing season (Figure 5)[199]. 

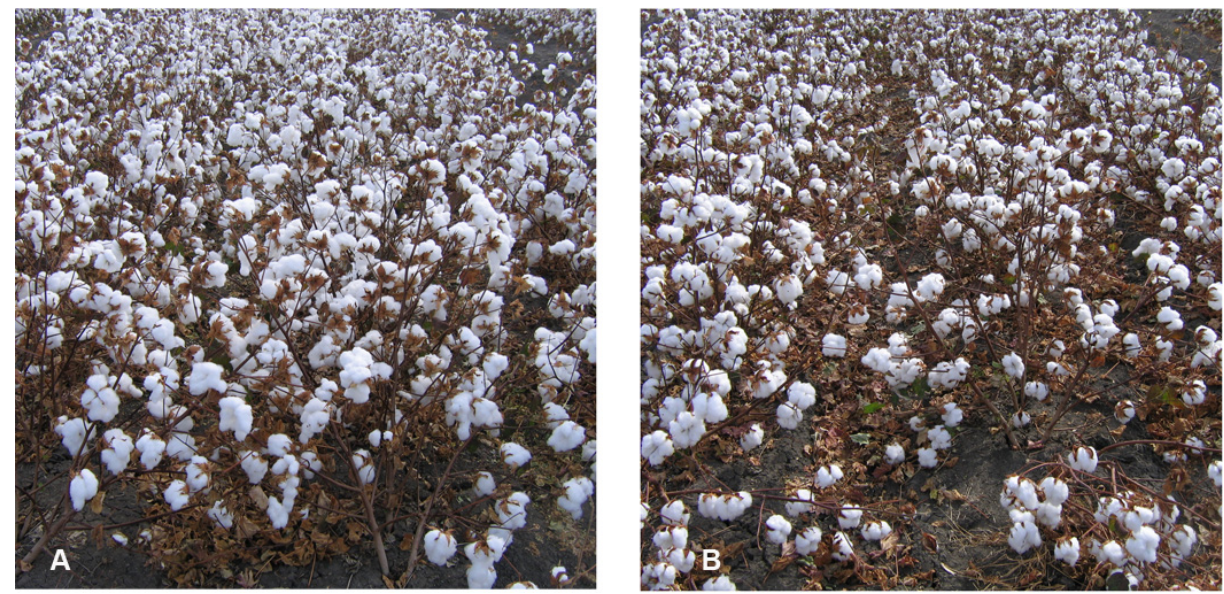

Figure 5. A higher number of cotton bolls were produced on field grown transgenic cotton producing NaPI and StPin1A (A) compared to Coker (B) the control non-transgenic parent

\subsection{Commercialisation of PIs and strategies to avoid resistance}

Since the first transgenic plants appeared almost two decades ago, this technology has contributed to the development of new approaches for crop protection [25]. There are numerous reports showing that expression of PIs in transgenic plants confers resistance to the intended target insects (see Table II; reviewed in $[61,215,242,243])$. However, many of the candidate genes that have been used in genetic transformation of crops have limited application because they do not have broad spectrum activity against the major insect pests or are only mildly effective against the target pests [52]. To overcome the development of insect resistance to transgenic plants expressing PIs, it is necessary to develop PIs that have broad activity against most or all of the proteases that the insects use for digestion. Several strategies have been proposed.

\subsubsection{Selecting second generation protease inhibitors from novel sources}

PI-resistant proteases probably result from the selection pressure imposed on insects when they encounter high endogenous PI levels in certain host plants [170]. Such selection for PIresistant proteases does not occur for PIs from non-host plants. Therefore, one approach to obtain better inhibitors for a particular insect pest is to search for PIs in plant species that are unrelated to the plant that is the normal host for that pest $[10,74,170]$. Another approach is to select PIs from synthetic libraries of mutant inhibitors for insect control [170].

\subsubsection{Use of multiple inhibitors}

Another strategy for controlling resistance development is to use at least two inhibitors that have different targets. This can be achieved by producing chimeric proteins, gene stacking (pyramiding) or the use a single inhibitors that have dual targets. Some examples of 
bifunctional inhibitors are alpha-amylase/trypsin inhibitors [8] and trypsin/ carboxypeptidase A inhibitors [244]. Similarly, expression of a fusion protein composed of a cystatin and a serine PI has been used to control certain nematode pathogens in transgenic plants [245]. Oppert and colleagues [246] demonstrated synergism between soybean Kunitz trypsin inhibitor and the cysteine protease inhibitor L-trans-epoxysuccinyleucylamide [4-guanidino] butane (E64) in artificial diet bioassays with Tribolium castaneum (red flour beetle, Coleoptera).

Transgenic tobacco plants expressing both a Bt-toxin and a cowpea trypsin inhibitor (CpTI) were more protected from $H$. armigera damage compared to transgenic tobacco expressing the Bt-toxin alone [247]. The enhanced insecticidal activity was attributed to enhanced stability of the Bt-toxin when the gut protease activity had been lowered [248,249]. In a separate set of experiments, $H$. armigera and $S$. litura larvae that consumed leaves from transgenic tobacco expressing avidin (from chicken egg white) that had been painted with Cry1Ba protein died significantly faster than larvae given either of the two treatments alone [38]. When used together in bioassays with artificial diet, the different and complementary action of Pot I (a chymotrypsin inhibitor) and CPI (a carboxpeptidase inhibitor) also resulted in a synergistic effect at reducing the growth rate of Cydia pomonella (codling moth) larvae [250]. However, the protective effects observed with PI gene constructs have not been sufficient to lead to a serious attempt at commercialising these transgenic crops.

\section{Summary}

The usefulness of insect-resistant transgenic plants has been widely demonstrated with the highly successfully implementation of crops that produce the Bt toxin. The current fear is that although Bt toxin has defended crops in the field for nearly 10 years now, the discovery of Bt resistance in H. zea populations in crop fields in the USA [251] and Bt resistance in populations of $D$. virgifera found in corn fields [148] might lead to widespread development of resistance to the Bt toxin. We have reported that two structurally different PIs that target different enzymes greatly improved the protection of transgenic cotton plants in the field. This supports the general consensus in the literature that no single insect trait will provide sustainable crop protection and that stacking of multiple insect traits that target different mechanisms should be employed.

\section{Author details}

Jackie Stevens, Kerry Dunse, Jennifer Fox, Shelley Evans and Marilyn Anderson* La Trobe Institute for Molecular Sciences, La Trobe University, Melbourne, Australia

\section{References}

[1] Krattiger AF (1996) Insect resistance in crops: A case study of Bacillus thuringiensis (Bt) and its transfer to developing countries: The International Agricultural Service for the Acquisition of Agribiotech Applications (ISAAA).

\footnotetext{
${ }^{*}$ Corresponding Author
} 
[2] Oerke EC (2006) Crop losses to pests. J Agric Sci 144: 31-43.

[3] Srinivasan A, Giri A, Gupta V (2006) Structural and functional diversities in lepidopteran serine proteases. Cell Mol Biol Lett 11: 132-154.

[4] Brooke E, Hines E (1999) Viral biopesticides for Heliothine control-fact of fiction? Today's Life Science 11: 38-45.

[5] Fitt GP (1994) Cotton Pest Management: Part 3. An Australian Perspective. Annu Rev Entomol 39: 532-562.

[6] Gatehouse AM, Hilder VA, Powell KS, Wang M, Davison GM, Gatehouse LN, Down RE, Edmonds HS, Boulter D, Newell CA, et al. (1994) Insect-resistant transgenic plants: choosing the gene to do the 'job'. Biochem Soc Trans 22: 944-949.

[7] Gunning RV, Easton CS, Balfe ME, Ferris IG (1991) Pyrethroid resistance mechanisms in Australian Helicoverpa armigera. Pestic Sci 33: 473-490.

[8] Haq SK, Atif SM, Khan RH (2004) Protein proteinase inhibitor genes in combat against insects, pests, and pathogens: natural and engineered phytoprotection. Arch Biochem Biophys 431: 145-159.

[9] Hilder VA, Gatehouse AM, Sheerman SE, Barker RF, Boulter D (1987) A novel mechanism of insect resistance engineered into tobacco. Nature 300: 160-163.

[10] Harsulkar AM, Giri AP, Patankar AG, Gupta VS, Sainani MN, Ranjekar PK, Deshpande VV (1999) Successive use of non-host plant proteinase inhibitors required for effective inhibition of Helicoverpa armigera gut proteinases and larval growth. Plant Physiol 121: 497-506.

[11] Xu D, Xue Q, McElroy D, Mawal Y, Hilder VA, Wu R (1996) Constitutive expression of a cowpea trypsin inhibitor gene, $\mathrm{CpTi}$, in transgenic rice plants confers resistance to two major rice insect pests. Mol Breed 2: 167-173.

[12] Bell HA, Fitches EC, Down RE, Ford L, Marris GC, Edwards JP, Gatehouse JA, Gatehouse AM (2001) Effect of dietary cowpea trypsin inhibitor (CpTI) on the growth and development of the tomato moth Lacanobia oleracea (Lepidoptera: Noctuidae) and on the success of the gregarious ectoparasitoid Eulophus pennicornis (Hymenoptera: Eulophidae). Pest Manage Sci 57: 57-65.

[13] Gatehouse AMR, Davison GM, Newell CA, Merryweather A, Hamilton WDO, Burgess EPJ, Gilbert RJC, Gatehouse JA (1997) Transgenic potato plants with enhanced resistance to the tomato moth, Lacanobia oleracea: growth room trials. Mol Breed 3: 49-63.

[14] Bravo A, Gill SS, Soberón M (2007) Mode of action of Bacillus thuringiensis Cry and Cyt toxins and their potential for insect control. Toxicon 49: 423-435.

[15] Pigott CR, Ellar DJ (2007) Role of receptors in Bacillus thuringiensis crystal toxin activity. Microbiol Mol Biol Rev 71: 255-+.

[16] Barton KA, Whiteley HR, Yang NS (1987) Bacillus thuringiensis §-Endotoxin Expressed in Transgenic Nicotiana tabacum Provides Resistance to Lepidopteran Insects. Plant Physiol 85: 1103-1109.

[17] Fischhoff DA, Bowdish KS, Perlak FJ, Marrone PG, Mccormick SM, Niedermeyer JG, Dean DA, Kusanokretzmer K, Mayer EJ, Rochester DE, Rogers SG, Fraley RT (1987) Insect Tolerant Transgenic Tomato Plants. Bio-Technology 5: 807-813. 
[18] Vaeck M, Reynaerts A, Höfte H, Jansens S, De Beuckeleer M, Dean C, Zabeau M, Van Montagu M, Leemans J (1987) Transgenic plants protected from insect attack. Nature 328: 33-37.

[19] James C (2011) Global status of Commercialized Biotech/GM Crops. ISAAA Brief No 43 Ithaca, NY, USA.

[20] Heckel DG, Gahan LJ, Baxter SW, Zhao JZ, Shelton AM, Gould F, Tabashnik BE (2007) The diversity of Bt resistance genes in species of Lepidoptera. J Invertebr Pathol 95: 192197.

[21] Tabashnik BE, Gassmann AJ, Crowder DW, Carrière Y (2008) Insect resistance to Bt crops: evidence versus theory. Nat Biotechnol 26: 199-202.

[22] Storer NP, Babcock JM, Schlenz M, Meade T, Thompson GD, Bing JW, Huckaba RM (2010) Discovery and characterization of field resistance to Bt maize: Spodoptera frugiperda (Lepidoptera: Noctuidae) in Puerto Rico. J Econ Entomol 103: 1031-1038.

[23] Van Rensburg J (2007) First report of field resistance by stem borer, Busseola fusca (Fuller) to Bt-transgenic maize. S Afr J Plant Soil 24: 147-150.

[24] Lynch RE, Guo B, Timper P, Wilson JP (2003) United States Department of AgricultureAgricultural Research Service: Research on improving host-plant resistance to pests. Pest Manage Sci 59: 718-727.

[25] Carlini CR, Grossi-de-Sa MF (2002) Plant toxic proteins with insecticidal properties. A review on their potentialities as bioinsecticides. Toxicon 40: 1515-1539.

[26] Franco OL, Rigden DJ, Melo FR, Grossi-de-Sa MF (2002) Plant alpha-amylase inhibitors and their interaction with insect alpha-amylases. Structure, function and potential for crop protection. Eur J Biochem 269: 397-412.

[27] Bhalla R, Dalal M, Panguluri SK, Jagadish B, Mandaokar AD, Singh AK, Kumar PA (2005) Isolation, characterization and expression of a novel vegetative insecticidal protein gene of Bacillus thuringiensis. FEMS Microbiol Lett 243: 467-472.

[28] Fang J, Xu XL, Wang P, Zhao JZ, Shelton AM, Cheng J, Feng MG, Shen ZC (2007) Characterization of chimeric Bacillus thuringiensis Vip3 toxins. Appl Environ Microbiol 73: 956-961.

[29] Kabir KE, Sugimoto H, Tado H, Endo K, Yamanaka A, Tanaka S, Koga D (2006) Effect of Bombyx mori chitinase against Japanese pine sawyer (Monochamus alternatus) adults as a biopesticide. Biosci Biotech Biochem 70: 219-229.

[30] Ferry N, Jouanin L, Ceci LR, Mulligan EA, Emami K, Gatehouse JA, Gatehouse AMR (2005) Impact of oilseed rape expressing the insecticidal serine protease inhibitor, mustard trypsin inhibitor-2 on the beneficial predator Pterostichus madidus. Mol Ecol 14: 337-349.

[31] Maheswaran G, Pridmore L, Franz P, Anderson MA (2007) A proteinase inhibitor from Nicotiana alata inhibits the normal development of light-brown apple moth, Epiphyas postvittana in transgenic apple plants. Plant Cell Rep 26: 773-782.

[32] Zhu C, Ruan L, Peng D, Yu Z, Sun M (2006) Vegetative insecticidal protein enhancing the toxicity of Bacillus thuringiensis subsp kurstaki against Spodoptera exigua. Lett Appl Microbiol 42: 109-114. 
[33] Estruch JJ, Warren GW, Mullins MA, Nye GJ, Craig JA, Koziel MG (1996) Vip3a, a Novel Bacillus Thuringiensis Vegetative Insecticidal Protein with a Wide Spectrum of Activities against Lepidopteran Insects. Proc Natl Acad Sci U S A 93: 5389-5394.

[34] Yu C, Mullins M, Warren G, Koziel M, Estruch J (1997) The Bacillus thuringiensis vegetative insecticidal protein Vip3A lyses midgut epithelium cells of susceptible insects. Appl Environ Microbiol 63: 532-536.

[35] Lee MK, Walters FS, Hart H, Palekar N, Chen JS (2003) Mode of action of the Bacillus thuringiensis vegetative insecticidal protein Vip3A differs from that of Cry1Ab deltaendotoxin. Appl Environ Microbiol 69: 4648-4657.

[36] Sellami S, Jamoussi K, Dabbeche E, Jaoua S (2011) Increase of the Bacillus thuringiensis Secreted Toxicity Against Lepidopteron Larvae by Homologous Expression of the vip3LB Gene During Sporulation Stage. Curr Microbiol 63: 289-294.

[37] Markwick N, Christeller J, Dochterty L, Lilley C (2001) Insecticidal activity of avidin and streptavidin against four species of pest Lepidoptera. Entomol Exp Appl 98: 59-66.

[38] Burgess EP, Malone LA, Christeller JT, Lester MT, Murray C, Philip BA, Phung MM, Tregidga EL (2002) Avidin expressed in transgenic tobacco leaves confers resistance to two noctuid pests, Helicoverpa armigera and Spodoptera litura. Transgenic Res 11: 185-198.

[39] Markwick NP, Docherty LC, Phung MM, Lester MT, Murray C, Yao JL, Mitra DS, Cohen D, Beuning LL, Kutty-Amma S, Christeller JT (2003) Transgenic tobacco and apple plants expressing biotin-binding proteins are resistant to two cosmopolitan insect pests, potato tuber moth and lightbrown apple moth, respectively. Transgenic Res 12: 671-681.

[40] Christeller JT, Malone LA, Todd JH, Marshall RM, Burgess EPJ, Philip BA (2005) Distribution and residual activity of two insecticidal proteins, avidin and aprotinin, expressed in transgenic tobacco plants, in the bodies and frass of Spodoptera litura larvae following feeding. J Insect Physiol 51: 1117-1126.

[41] Murray C, Markwick NP, Kaji R, Poulton J, Martin H, Christeller JT (2010) Expression of various biotin-binding proteins in transgenic tobacco confers resistance to potato tuber moth, Phthorimaea operculella (Zeller) (fam. Gelechiidae). Transgenic Res 19: 1041-1051.

[42] Ding XF, Gopalakrishnan B, Johnson LB, White FF, Wang XR, Morgan TD, Kramer KJ, Muthukrishnan S (1998) Insect Resistance of Transgenic Tobacco Expressing an Insect Chitinase Gene. Transgenic Res 7: 77-84.

[43] Fitches E, Wilkinson H, Bell H, Bown DP, Gatehouse JA, Edwards JP (2004) Cloning, expression and functional characterisation of chitinase from larvae of tomato moth (Lacanobia oleracea): a demonstration of the insecticidal activity of insect chitinase. Insect Biochem Mol Biol 34: 1037-1050.

[44] Wang JX, Chen ZL, Du JZ, Sun Y, Liang AH (2005) Novel insect resistance in Brassica napus developed by transformation of chitinase and scorpion toxin genes. Plant Cell Rep 24: 549-555.

[45] Purcell JP, Greenplate JT, Jennings MG, Ryerse JS, Pershing JC, Sims SR, Prinsen MJ, Corbin DR, Tran M, Sammons RD, Stonard RJ (1993) Cholesterol Oxidase- A Potent Insecticidal Protein Active against Boll-Weevil Larvae. Biochem Biophys Res Commun 196: 1406-1413. 
[46] Corbin DR, Grebenok RJ, Ohnmeiss TE, Greenplate JT, Purcell JP (2001) Expression and chloroplast targeting of cholesterol oxidase in transgenic tobacco plants. Plant Physiol 126: $1116-1128$.

[47] Shukle RH, Murdock LL (1983) Lipoxygenase, trypsin inhibitor and lectin from soybeans: effects on larval growth of Manduca sexta (Lepidoptera: Sphingidae). Environ Entomol 12: 787-791.

[48] Schroeder HE, Gollasch S, Moore A, Tabe LM, Craig S, Hardie DC, Chrispeels MJ, Spencer D, Higgins TJV (1995) Bean $\alpha$-Amylase Inhibitor Confers Resistance to the Pea Weevil (Bruchus pisorum) in Transgenic Peas (Pisum sativum L.). Plant Physiol 107: 12331239.

[49] Ishimoto M, Chrispeels MJ (1996) Protective mechanism of the Mexican bean weevil against high levels of alpha-amylase inhibitor in the common bean. Plant Physiol 111: 393-401.

[50] Morton RL, Schroeder HE, Bateman KS, Chrispeels MJ, Armstrong E, Higgins TJV (2000) Bean alpha-amylase inhibitor 1 in transgenic peas (Pisum sativum ) provides complete protection from pea weevil (Bruchus pisorum ) under field conditions. Proc Natl Acad Sci U S A 97: 3820-3825.

[51] Valencia-Jimenez A, Arboleda JW, Avila AL, Grossi-de-Sa MF (2008) Digestive alphaamylases from Tecia solanivora larvae (Lepidoptera: Gelechiidae): response to $\mathrm{pH}$, temperature and plant amylase inhibitors. Bull Entomol Res 98: 575-579.

[52] Sharma HC, Sharma KK, Seetharama N, Ortiz R (2000) Prospects for using transgenic resistance to insects in crop improvement. Electron J Biotechnol 3: 76-95.

[53] Czapla TH, Lang BA (1990) Effects of plant lectins on the larval development of European corn boror (Lepidoptera: Pyralidae) and Southern corn rootworm (Coleoptera: Chrysomelidae). J Econ Entomol 83: 2480-2485.

[54] Hopkins TL, Harper MS (2001) Lepidopteran peritrophic membranes and effects of dietary wheat germ agglutinin on their formation and structure. Arch Insect Biochem Physiol 47: 100-109.

[55] Fitches E, Gatehouse JA (1998) A comparison of the short and long term effects of insecticidal lectins on the activities of soluble and brush border enzymes of tomato moth larvae (Lacanobia oleracea). J Insect Physiol 44: 1213-1224.

[56] Down RE, Ford L, Bedford SJ, Gatehouse LN, Newell C, Gatehouse JA, Gatehouse AMR (2001) Influence of plant development and environment on transgene expression in potato and consequences for insect resistance. Transgenic Res 10: 223-236.

[57] Sadeghi A, Smagghe G, Broeders S, Hernalsteens JP, De Greve H, Peumans WJ, Van Damme EJ (2008) Ectopically expressed leaf and bulb lectins from garlic (Allium sativum L.) protect transgenic tobacco plants against cotton leafworm (Spodoptera littoralis). Transgenic Res 17: 9-18.

[58] de Oliveira CFR, Luz LA, Paiva PMG, Coelho L, Marangoni S, Macedo MLR (2011) Evaluation of seed coagulant Moringa oleifera lectin (cMoL) as a bioinsecticidal tool with potential for the control of insects. Process Biochem 46: 498-504. 
[59] Nauen R, Sorge D, Sterner A, Borovsky D (2001) TMOF-like factor controls the biosynthesis of serine proteases in the larval gut of Heliothis virescens. Arch Insect Biochem Physiol 47: 169-180.

[60] Tortiglione C, Fanti P, Pennacchio F, Malva C, Breuer M, De Loof A, Monti LM, Tremblay E, Rao R (2002) The expression in tobacco plants of Aedes aegypti Trypsin Modulating Oostatic Factor (Aea-TMOF) alters growth and development of the tobacco budworm, Heliothis virescens. Mol Breed 9: 159-169.

[61] Schuler TH, Poppy GM, Kerry BR, Denholm I (1998) Insect-resistant transgenic plants. Trends Biotechnol 16: 168-175.

[62] Harvey WR (1992) Physiology of V-ATPases. J Exp Biol 172: 1-17.

[63] Baum JA, Bogaert T, Clinton W, Heck GR, Feldmann P, Ilagan O, Johnson S, Plaetinck G, Munyikwa T, Pleau M, Vaughn T, Roberts J (2007) Control of coleopteran insect pests through RNA interference. Nat Biotechnol 25: 1322-1326.

[64] Mao YB, Cai WJ, Wang JW, Hong GJ, Tao XY, Wang LJ, Huang YP, Chen XY (2007) Silencing a cotton bollworm P450 monooxygenase gene by plant-mediated RNAi impairs larval tolerance of gossypol. Nat Biotechnol 25: 1307-1313.

[65] Bettencourt R, Terenius O, Faye I (2002) Hemolin gene silencing by ds-RNA injected into Cecropia pupae is lethal to next generation embryos. Insect Mol Biol 11: 267-271.

[66] Eleftherianos I, Marokhazi J, Millichap PJ, Hodgkinson AJ, Sriboonlert A, ffrenchConstant RH, Reynolds SE (2006) Prior infection of Manduca sexta with non-pathogenic Escherichia coli elicits immunity to pathogenic Photorhabdus luminescens: roles of immune-related proteins shown by RNA interference. Insect Biochem Mol Biol 36: 517525.

[67] Fitt GP (1989) The ecology of Heliothis species in relation to agroecosystems. Annu Rev Entomol 34: 17-52.

[68] Trowell SC, Forrester NW, Garsia KA, Lang GA, Bird LJ, Hill AS, Skerritt JH, Daly JC (2000) Rapid antibody-based field test to distinguish between Helicoverpa armigera (Lepidoptera: Noctuidae) and Helicoverpa punctigera (Lepidoptera: Noctuidae). J Econ Entomol 93: 878-891.

[69] Sivakumar S, Rajagopal R, Venkatesh GR, Srivastava A, Bhatnagar RK (2007) Knockdown of aminopeptidase-N from Helicoverpa armigera larvae and in transfected Sf21 cells by RNA interference reveals its functional interaction with Bacillus thuringiensis insecticidal protein Cry1Ac. J Biol Chem 282: 7312-7319.

[70] Estébanez-Perpiñá E, Bayés A, Vendrell J, Jongsma MA, Bown DP, Gatehouse JA, Huber R, Bode W, Avilés FX, Reverter D (2001) Crystal structure of a novel Mid-gut procarboxypeptidase from the cotton pest Helicoverpa armigera. J Mol Biol 313: 629-638.

[71] Downes S, Mahon R, Olsen K (2007) Monitoring and adaptive resistance management in Australia for Bt-cotton: Current status and future challenges. J Invertebr Pathol 95: 208-213.

[72] Patankar AG, Giri AP, Harsulkar AM, Sainani MN, Deshpande VV, Ranjekar PK, Gupta VS (2001) Complexity in specificities and expression of Helicoverpa armigera gut proteinases explains polyphagous nature of the insect pest. Insect Biochem Mol Biol 31: 453-464. 
[73] Daly JC, Gregg P (1985) Genetic variation in Heliothis in Australia: Species identification and gene flow in the two pest species $H$. armigera (Hubner) and $H$. punctigera Wallengren (Lepidoptera: Noctuidae). Bull Entomol Res 75: 169-184.

[74] Duan X, Li X, Xue Q, Abo-Ei-Saad M, Xu D, Wu R (1996) Transgenic rice plants harboring an introduced potato proteinase inhibitor II gene are insect resistant. Nat Biotech 14: 494-498.

[75] Grundy PR (2007) Utilizing the assassin bug, Pristhesancus plagipennis (Hemiptera : Reduviidae), as a biological control agent within an integrated pest management programme for Helicoverpa spp. (Lepidoptera : Noctuidae) and Creontiades spp. (Hemiptera : Miridae) in cotton. Bull Entomol Res 97: 281-290.

[76] Xu D, McElroy D, Thornburg RW, Wu R (1993) Systemic induction of a potato pin2 promoter by wounding, methyl jasmonate, and abscisic acid in transgenic rice plants. Plant Mol Biol 22: 573.

[77] Basinski JMH, Bendena WG, Downe AER (1995) The Effect of CfNPV Infection on Several Proteases in the Midgut of the Eastern Spruce Budworm Choristoneura fumiferana. J Invertebr Pathol 66: 264-269.

[78] Borovsky D, Rabindran S, Dawson WO, Powell CA, Iannotti DA, Morris TJ, Shabanowitz J, Hunt DF, DeBondt HL, DeLoof A (2006) Expression of Aedes trypsinmodulating oostatic factor on the virion of TMV: A potential larvicide. Proc Natl Acad Sci U S A 103: 18963-18968.

[79] Murdock LL, Huesing JE, Nielsen SS, Pratt RC, Shade RE (1990) Biological effects of plant lectins on the cowpea weevil. Phytochemistry 29: 85-89.

[80] Eisemann CH, Donaldson RA, Pearson RD, Cadogan LC, Vuocolo T, Tellam RL (1994) Larvicidal Activity of Lectins on Lucilia Cuprina - Mechanism of Action. Entomol Exp Appl 72: 1-10.

[81] Harper MS, Hopkins TL, Czapla TH (1998) Effect of wheat germ agglutinin on formation and structure of the peritrophic membrane in European corn borer (Ostrinia nubilalis) larvae. Tissue and Cell 30: 166-176.

[82] Williams IS (1999) Slow-growth, high-mortality - a general hypothesis, or is it? Ecol Entomol 24: 490-495.

[83] Lopes AR, Juliano MA, Juliano L, Terra WR (2004) Coevolution of insect trypsins and inhibitors. Arch Insect Biochem Physiol 55: 140-152.

[84] Zavala JA, Baldwin IT (2004) Fitness benefits of trypsin proteinase inhibitor expression in Nicotiana attenuata are greater than their costs when plants are attacked. BMC Ecol 4: 11.

[85] Silva FC, Alcazar A, Macedo LL, Oliveira AS, Macedo FP, Abreu LR, Santos EA, Sales MP (2006) Digestive enzymes during development of Ceratitis capitata (Diptera:Tephritidae) and effects of SBTI on its digestive serine proteinase targets. Insect Biochem Mol Biol 36: 561-569.

[86] Room PM (1979) Parasites and predators of Heliothis spp. (Lepidoptera: Noctuidae) in cotton in the Namoi Valley, New South Wales. J Aust Entomol Soc 18: 223-228. 
[87] Hellers M, Beck M, Theopold U, Kamei M, Schmidt O (1996) Multiple alleles encoding a virus-like particle protein in the ichneumonid endoparasitoid Venturia canescens. Insect Mol Biol 5: 239-249.

[88] Malone LA, Giacon HA, Burgess EPJ, Maxwell JZ, Christeller JT, Laing WA (1995) Toxicity of Trypsin Endopeptidase Inhibitors to Honey Bees (Hymenoptera, Apidae). J Econ Entomol 88: 46-50.

[89] Burgess EPJ, Malone LA, Christeller JT (1996) Effects of two proteinase inhibitors on the digestive enzymes and survival of honey bees (Apis mellifera). J Insect Physiol 42: 823828.

[90] Burgess EPJ, Lovei GL, Malone LA, Nielsen IW, Gatehouse HS, Christeller JT (2002) Prey-mediated effects of the protease inhibitor aprotinin on the predatory carabid beetle Nebria brevicollis. J Insect Physiol 48: 1093-1101.

[91] Shimizu T, Yoshii M, Wei T, Hirochika H, Omura T (2009) Silencing by RNAi of the gene for Pns12, a viroplasm matrix protein of Rice dwarf virus, results in strong resistance of transgenic rice plants to the virus. Plant Biotechnol J 7: 24-32.

[92] Duke SO (2011) Comparing conventional and biotechnology-based pest management. J Agric Food Chem 59: 5793-5798.

[93] James C (2009) Global status of commercialized biotech/GM crops: 2009. In: ISAAA: Ithaca N, editor. ISAAA Brief No 41. pp. Ithaca, NY, USA.

[94] Brookes G, Barfoot P (2005) GM Crops: The Global Economic and Environmental Impact-The First Nine Years 1996-2004. AgBioForum 8: 187-196.

[95] Downes S, Wilson L, Knight K, Kauter G, Leven T (2012) Preamble to the Resistance Management Plan (RMP) for Bollgard II 20011/12. Cotton pest management guide 20112012: Cotton Catchment Communities. pp. 74-87

(http://www.cottoncrc.org.au/industry/Publications/Cotton_Pest_Management_Guide_20 11_2012).

[96] Schnepf E, Crickmore N, van Rie J, Lereclus D, Baum J, Feitelson J, Zeigler DR, Dean $\mathrm{DH}$ (1998) Bacillus thuringiensis and its pesticidal crystal proteins. Microbiol Mol Biol Rev 62: 775-806.

[97] Höfte H, Whiteley HR (1989) Insecticidal crystal proteins of Bacillus thuringiensis. Micro Rev 53: 242-255.

[98] Crickmore N, Zeigler DR, Feitelson J, Schnepf E, Van Rie J, Lereclus D, Baum J, Dean DH (1998) Revision of the nomenclature for the Bacillus thuringiensis pesticidal crystal proteins. Microbiol Mol Biol Rev 62: 807-813.

[99] van Frankenhuyzen K (2009) Insecticidal activity of Bacillus thuringiensis crystal proteins. J Invertebr Pathol 101: 1-16.

[100] Tabashnik BE, Van Rensburg JBJ, Carrière Y (2009) Field-evolved insect resistance to Bt crops: definition, theory, and data. J Econ Entomol 102: 2011-2025.

[101] Knowles BH, Dow JAT (1993) The crystal $\delta$-endotoxins of Bacillus thuringiensis: models for their mechanism of action on the insect gut. Bioessays 15: 469-476.

[102] Marvier M, McCreedy C, Regetz J, Kareiva P (2007) A meta-analysis of effects of Bt cotton and maize on nontarget invertebrates. Science 316: 1475-1477. 
[103] Romeis J, Meissle M, Bigler F (2006) Transgenic crops expressing Bacillus thuringiensis toxins and biological control. Nat Biotechnol 24: 63-71.

[104] Endo Y, Nishiitsutsuji-Uwo (1980) Mode of action of Bacillus thuringiensis $\delta$-endotoxin: Histopathological changes in the silkworm midgut. J Invertebr Pathol 36: 90-103.

[105] Estela A, Escriche B, Ferré J (2004) Interaction of Bacillus thuringiensis toxins with larval midgut binding sites of Helicoverpa armigera (Lepidoptera : Noctuidae). Appl Environ Microbiol 70: 1378-1384.

[106] Ryerse JS, Beck JR, Jr., Lavrik PB (1990) Light microscope immunolocation of Bacillus thuringiensis kurstaki delta-endotoxin in the midgut and Malpighian tubules of the tobacco budworm, Heliothis virescens. J Invertebr Pathol 56: 86-90.

[107] MacIntosh SC, Stone TB, Jokerst RS, Fuchs RL (1991) Binding of Bacillus thuringiensis proteins to a laboratory-selected line of Heliothis virescens. Proc Natl Acad Sci U S A 88: 8930-8933.

[108] Lane NJ, Harrison JB, Lee WM (1989) Changes in microvilli and Golgi-associated membranes of lepidopteran cells induced by an insecticidally active bacterial $\delta$ endotoxin. J Cell Sci 93: 337-347.

[109] Knight PJ, Crickmore N, Ellar DJ (1994) The receptor for Bacillus thuringiensis CrylA(c) delta-endotoxin in the brush border membrane of the lepidopteran Manduca sexta is aminopeptidase N. Mol Microbiol 11: 429-436.

[110] Hua G, Masson L, Jurat-Fuentes JL, Schwab G, Adang MJ (2001) Binding analyses of Bacillus thuringiensis Cry $\delta$-endotoxins using brush border membrane vesicles of Ostrinia nubilalis. Appl Environ Microbiol 67: 872-879.

[111] Li HR, Oppert B, Higgins RA, Huang FN, Zhu KY, Buschman LL (2004) Comparative analysis of proteinase activities of Bacillus thuringiensis-resistant and susceptible Ostrinia nubilalis (Lepidoptera : Crambidae). Insect Biochem Mol Biol 34: 753-762.

[112] Siqueira HAA, Nickerson KW, Moellenbeck D, Siegfried BD (2004) Activity of gut proteinases from Cry1 Ab-selected colonies of the European corn borer, Ostrinia nubilalis (Lepidoptera: Crambidae). Pest Manage Sci 60: 1189-1196.

[113] Tang JD, Shelton AM, Vanrie J, Deroeck S, Moar WJ, Roush RT, Peferoen M (1996) Toxicity of Bacillus Thuringiensis Spore and Crystal Protein to Resistant Diamondback Moth (Plutella Xylostella). Appl Environ Microbiol 62: 564-569.

[114] Wright DJ, Iqbal M, Granero F, Ferré J (1997) A change in a single midgut receptor in the diamondback moth (Plutella xylostella) is only in part responsible for field resistance to Bacillus thuringiensis subsp. kurstaki and B. thuringiensis subsp. aizawai. Appl Environ Microbiol 63: 1814-1819.

[115] Gonzalez-Cabrera J, Farinos GP, Caccia S, Diaz-Mendoza M, Castanera P, Leonardi MG, Giordana B, Ferre J (2006) Toxicity and mode of action of Bacillus thuringiensis cry proteins in the Mediterranean corn borer, Sesamia nonagrioides (Lefebvre). Appl Environ Microbiol 72: 2594-2600.

[116] Moar WJ, Pusztaicarey M, Vanfaassen H, Bosch D, Frutos R, Rang C, Luo K, Adang MJ (1995) Development of Bacillus thuringiensis CryIC resistance by Spodoptera exigua (Hubner) (Lepidoptera, Noctuidae). Appl Environ Microbiol 61: 2086-2092. 
[117] Adamczyk JJ, Holloway JW, Church GE, Leonard BR, Graves JB (1998) Larval Survival and Development of the Fall Armyworm (Lepidoptera: Noctuidae) on Normal and Transgenic Cotton Expressing the Bacillus thuringiensis CryIA (c)-endotoxin. J Econ Entomol 91: 539-545.

[118] Avisar D, Keller M, Gazit E, Prudovsky E, Sneh B, Zilberstein A (2004) The role of Bacillus thuringiensis Cry1C and Cry1E separate structural domains in the interaction with Spodoptera littoralis gut epithelial cells. J Biol Chem 279: 15779-15786.

[119] Gill SS, Cowles EA, Pietrantonio PV (1992) The mode of action of Bacillus thuringiensis endotoxins. Annu Rev Entomol 37: 615-636.

[120] Dow JAT, Evans PD, Wigglesworth VB (1987) Insect Midgut Function. Adv Insect Physiol: Academic Press. pp. 187-328.

[121] Bietlot H, Carey PR, Choma C, Kaplan H, Lessard T, Pozsgay M (1989) Facile preparation and characterization of the toxin from Bacillus thuringiensis var. kurstaki. Biochem J 260: 87-91.

[122] Nagamatsu Y, Itai Y, Hatanaka C, Funatsu G, Hayashi K (1984) A toxic fragment from the entomocidal crystal protein of Bacillus thuringiensis. Agric Biol Chem 48: 611-619.

[123] Tojo A, Aizawa K (1983) Dissolution and degradation of Bacillus thuringiensis $\delta$ endotoxin by gut juice protease of the silkworm Bombyx mori. Appl Environ Microbiol 45: 576-580.

[124] Diaz-Mendoza M, Farinós GP, Castañera P, Hernández-Crespo P, Ortego F (2007) Proteolytic processing of native Cry1 $\mathrm{Ab}$ toxin by midgut extracts and purified trypsins from the Mediterranean corn borer Sesamia nonagrioides. J Insect Physiol 53: 428-435.

[125] Rukmini V, Reddy CY, Venkateswerlu G (2000) Bacillus thuringiensis crystal $\delta$ endotoxin: role of proteases in the conversion of protoxin to toxin. Biochimie 82: 109116.

[126] Knowles BH, Ellar DJ (1987) Colloid-osmotic lysis is a general feature of the mechanism of action of Bacillus thuringiensis [delta]-endotoxins with different insect specificity. BBA-General Subjects 924: 509-518.

[127] Haider MZ, Ellar DJ (1989) Mechanism of action of Bacillus thuringiensis insecticidal $\delta$ endotoxin: interaction with phospholipid vesicles. Biochimica et Biophysica Acta (BBABiomembranes) - Biomembranes 978: 216-222.

[128] Bravo A, Gómez I, Conde J, Muñoz-Garay C, Sánchez J, Miranda R, Zhuang M, Gill SS, Soberón M (2004) Oligomerization triggers binding of a Bacillus thuringiensis Cry1 Ab pore-forming toxin to aminopeptidase $\mathrm{N}$ receptor leading to insertion into membrane microdomains. Biochim Biophys Acta (BBA-Biomembranes), Biomembr 1667: 38-46.

[129] Vadlamudi RK, Weber E, Ji I, Ji TH, Bulla LA, Jr. (1995) Cloning and expression of a receptor for an insecticidal toxin of Bacillus thuringiensis. J Biol Chem 270: 5490-5494.

[130] Vadlamudi RK, Ji TH, Bulla LA, Jr. (1993) A specific binding protein from Manduca sexta for the insecticidal toxin of Bacillus thuringiensis subsp. berliner. J Biol Chem 268: 12334-12340.

[131] Jurat-Fuentes JL, Adang MJ (2004) Characterization of a Cry1Ac-receptor alkaline phosphatase in susceptible and resistant Heliothis virescens larvae. Eur J Biochem 271: 3127-3135. 
[132] Jurat-Fuentes JL, Gahan LJ, Gould FL, Heckel DG, Adang MJ (2004) The HevCaLP protein mediates binding specificity of the Cry1A class of Bacillus thuringiensis toxins in Heliothis virescens. Biochemistry 43: 14299-14305.

[133] Nagamatsu Y, Toda S, Yamaguchi F, Ogo M, Kogure M, Nakamura M, Shibata Y, Katsumoto $\mathrm{T}$ (1998) Identification of Bombyx mori midgut receptor for Bacillus thuringiensis insecticidal CryIA(a) toxin. Biosci Biotechnol Biochem 62: 718-726.

[134] Gómez I, Sánchez J, Miranda R, Bravo A, Soberón M (2002) Cadherin-like receptor binding facilitates proteolytic cleavage of helix $\alpha-1$ in domain I and oligomer pre-pore formation of Bacillus thuringiensis Cry1Ab toxin. FEBS lett 513: 242-246.

[135] Knight PJK, Crickmore N, Ellar DJ (1994) The receptor for Bacillus thuringiensis CrylA (c) delta-endotoxin in the brush border membrane of the lepidopteran Manduca sexta is aminopeptidase N. Mol Microbiol 11: 429-436.

[136] Knowles BH (1994) Mechanism of action of Bacillus thuringiensis insecticidal dendotoxins. Adv Insect Physiol 24: 275-308.

[137] Jiménez-Juárez N, Muñoz-Garay C, Gómez I, Saab-Rincon G, Damian-Almazo JY, Gill SS, Soberón M, Bravo A (2007) Bacillus thuringiensis Cry1Ab mutants affecting oligomer formation are non-toxic to Manduca sexta larvae. J Biol Chem 282: 21222-21229.

[138] Soberón M, Pardo-López L, López I, Gómez I, Tabashnik BE, Bravo A (2007) Engineering modified Bt toxins to counter insect resistance. Science 318: 1640-1642.

[139] Tabashnik BE, Huang F, Ghimire MN, Leonard BR, Siegfried BD, Rangasamy M, Yang Y, Wu Y, Gahan LJ, Heckel DG, Bravo A, Soberón M (2011) Efficacy of genetically modified Bt toxins against insects with different genetic mechanisms of resistance. Nat Biotechnol 29: 1128-1131.

[140] Zhang X, Candas M, Griko NB, Taussig R, Bulla LA, Jr. (2006) A mechanism of cell death involving an adenylyl cyclase/PKA signaling pathway is induced by the Cry1 Ab toxin of Bacillus thuringiensis. Proc Natl Acad Sci U S A 103: 9897-9902.

[141] Zhang X, Candas M, Griko NB, Rose-Young L, Bulla LA (2005) Cytotoxicity of Bacillus thuringiensis Cry1 $\mathrm{Ab}$ toxin depends on specific binding of the toxin to the cadherin receptor BT-R-1 expressed in insect cells. Cell Death Differ 12: 1407-1416.

[142] Bagla P (2010) Hardy Cotton-Munching Pests Are Latest Blow to GM Crops. Science 327: 1439.

[143] Dhurua S, Gujar GT (2011) Field-evolved resistance to Bt toxin Cry1Ac in the pink bollworm, Pectinophora gossypiella (Saunders) (Lepidoptera: Gelechiidae), from India. Pest Manage Sci 67: 898-903.

[144] Luttrell RG, Wan L, Knighten K (1999) Variation in susceptibility of noctuid (Lepidoptera) larvae attacking cotton and soybean to purified endotoxin proteins and commercial formulations of Bacillus thuringiensis. J Econ Entomol 92: 21-32.

[145] Ali MI, Luttrell RG, Young SY, III (2006) Susceptibilities of Helicoverpa zea and Heliothis virescens (Lepidoptera: Noctuidae) populations to Cry1Ac insecticidal protein. J Econ Entomol 99: 164-175.

[146] Ali MI, Luttrell RG (2007) Susceptibility of bollworm and tobacco budworm (Lepidoptera: Noctuidae) to Cry2Ab2 insecticidal protein. J Econ Entomol 100: 921-931. 
[147] Carrière Y, Crowder DW, Tabashnik BE (2010) Evolutionary ecology of insect adaptation to Bt crops. Evol Appl 3: 561-573.

[148] Gassmann AJ, Petzold-Maxwell JL, Keweshan RS, Dunbar MW (2011) Field-Evolved Resistance to Bt Maize by Western Corn Rootworm. PLoS One 6: e22629.

[149] Moar W, Roush R, Shelton A, Ferré J, MacIntosh S, Leonard BR, Abel C (2008) Fieldevolved resistance to Bt toxins. Nat Biotechnol 26: 1072-1074.

[150] Tabashnik B, Carriere Y (2009) Insect resistance to genetically modified crops. Environmental impact of genetically modified crops Wallingford: CABI: 74-100.

[151] Kruger M, Van Rensburg J, Van den Berg J (2009) Perspective on the development of stem borer resistance to $\mathrm{Bt}$ maize and refuge compliance at the Vaalharts irrigation scheme in South Africa. Crop Protect 28: 684-689.

[152] Tiewsiri K, Wang P (2011) Differential alteration of two aminopeptidases N associated with resistance to Bacillus thuringiensis toxin Cry1Ac in cabbage looper. Proc Natl Acad Sci U S A 108: 14037-14042.

[153] Jurat-Fuentes JL, Karumbaiah L, Jakka SRK, Ning C, Liu C, Wu K, Jackson J, Gould F, Blanco C, Portilla M, Perera O, Adang MJ (2011) Reduced levels of membrane-bound alkaline phosphatase are common to Lepidopteran strains resistant to Cry toxins from Bacillus thuringiensis. PLoS One 6: e17606.

[154] Gahan LJ, Gould F, Heckel DG (2001) Identification of a gene associated with Bt resistance in Heliothis virescens. Science 293: 857-860.

[155] Yang Y, Chen H, Wu Y, Wu S (2007) Mutated cadherin alleles from a field population of Helicoverpa armigera confer resistance to Bacillus thuringiensis toxin Cry1Ac. Appl Environ Microbiol 73: 6939-6944.

[156] Morin S, Biggs RW, Sisterson MS, Shriver L, Ellers-Kirk C, Higginson D, Holley D, Gahan LJ, Heckel DG, Carriere Y, Dennehy TJ, Brown JK, Tabashnik BE (2003) Three cadherin alleles associated with resistance to Bacillus thuringiensis in pink bollworm. Proc Natl Acad Sci U S A 100: 5004-5009.

[157] Baxter SW, Badenes-Pérez FR, Morrison A, Vogel H, Crickmore N, Kain W, Wang P, Heckel DG, Jiggins CD (2011) Parallel evolution of Bacillus thuringiensis toxin resistance in Lepidoptera. Genetics 189: 675-679.

[158] Huang FN, Zhu KY, Buschman LL, Higgins RA, Oppert B (1999) Comparison of midgut proteinases in Bacillus thuringiensis-susceptible and resistant European corn borer, Ostrinia nubilalis (Lepidoptera : Pyralidae). Pestic Biochem Physiol 65: 132-139.

[159] Li HR, Oppert B, Higgins RA, Huang FN, Buschman LL, Gao JR, Zhu KY (2005) Characterization of cDNAs encoding three trypsin-like proteinases and mRNA quantitative analysis in Bt-resistant and -susceptible strains of Ostrinia nubilalis. Insect Biochem Mol Biol 35: 847-860.

[160] Tabashnik BE, Croft BA (1982) Managing Pesticide Resistance in Crop-Arthropod Complexes: Interactions Between Biological and Operational Factors. Environ Entomol 11: 1137-1144.

[161] Gould F (1998) Sustainability of transgenic insecticidal cultivars: integrating pest genetics and ecology. Annu Rev Entomol 43: 701-726. 
[162] Tabashnik BE, Carriere Y (2004) Bt transgenic crops do not have favorable effects on resistant insects. J Insect Sci 4: 4.

[163] Roush RT (1998) Two-toxin strategies for management of insecticidal transgenic crops: can pyramiding succeed where pesticide mixtures have not? Philos Trans R Soc Lond, Ser B: Biol Sci 353: 1777-1786.

[164] Ferré J, Van Rie J (2002) Biochemistry and genetics of insect resistance to Bacillus thuringiensis. Annu Rev Entomol 47: 501-533.

[165] Moar WJ, Anilkumar KJ (2007) The power of the pyramid. Science 318: 1561-1562.

[166] Alcantara EP, Aguda RM, Curtiss A, Dean DH, Cohen MB (2004) Bacillus thuringiensis $\delta$-endotoxin binding to brush border membrane vesicles of rice stem borers. Arch Insect Biochem Physiol 55: 169-177.

[167] Hernández CS, Ferré J (2005) Common receptor for Bacillus thuringiensis toxins Cry1Ac, Cry1Fa, and Cry1Ja in Helicoverpa armigera, Helicoverpa zea, and Spodoptera exigua. Appl Environ Microbiol 71: 5627-5629.

[168] Naranjo SE (2011) Impacts of Bt Transgenic Cotton on Integrated Pest Management. J Agric Food Chem 59: 5842-5851.

[169] Ryan CA (1990) Protease Inhibitors in Plants: Genes for Improving Defenses Against Insects and Pathogens. Annu Rev Phytopathol 28: 425.

[170] Jongsma MA, Stiekema WJ, Bosch D (1996) Combatting inhibitor-insensitive proteases of insect pests. Trends Biotechnol 14: 331-333.

[171] Ryan CA (1989) Proteinase inhibitor gene families: strategies for transformation to improve plant defenses against herbivores. Bioessays 10: 20-22.

[172] Tamayo MC, Rufat M, Bravo JM, San Segundo B (2000) Accumulation of a maize proteinase inhibitor in response to wounding and insect feeding, and characterization of its activity toward digestive proteinases of Spodoptera littoralis larvae. Planta 211: 6271.

[173] Farmer EE, Ryan CA (1990) Interplant communication: airborne methyl jasmonate induces synthesis of proteinase inhibitors in plant leaves. Proc Natl Acad Sci U S A 87: 7713-7716.

[174] Gatehouse AM, Norton E, Davison GM, Babbe SM, Newell CA, Gatehouse JA (1999) Digestive proteolytic activity in larvae of tomato moth, Lacanobia oleracea; effects of plant protease inhibitors in vitro and in vivo. J Insect Physiol 45: 545-558.

[175] Gomes A, Dias SC, Bloch C, Jr., Melo FR, Furtado JR, Jr., Monnerat RG, Grossi-de-Sa MF, Franco OL (2005) Toxicity to cotton boll weevil Anthonomus grandis of a trypsin inhibitor from chickpea seeds. Comp Biochem Physiol B Biochem Mol Biol 140B: 313319.

[176] Gomes CE, Barbosa AE, Macedo LL, Pitanga JC, Moura FT, Oliveira AS, Moura RM, Queiroz AF, Macedo FP, Andrade LB, Vidal MS, Sales MP (2005) Effect of trypsin inhibitor from Crotalaria pallida seeds on Callosobruchus maculatus (cowpea weevil) and Ceratitis capitata (fruit fly). Plant Physiol Biochem 43: 1095-1102.

[177] Burgess E, Main C, Stevens P, Christeller J, Gatehouse A, Laing W (1994) Effects of protease inhibitor concentration and combinations on the survival, growth and gut 
enzyme activities of the black field cricket, Teleogryllus commodus. J Insect Physiol 40: 803-811.

[178] De Leo F, Bonadé-Bottino M, Ruggiero Ceci L, Gallerani R, Jouanin L (2001) Effects of a mustard trypsin inhibitor expressed in different plants on three lepidopteran pests. Insect Biochem Mol Biol 31: 593-602.

[179] Tamhane VA, Giri AP, Sainani MN, Gupta VS (2007) Diverse forms of Pin-II family proteinase inhibitors from Capsicum annuum adversely affect the growth and development of Helicoverpa armigera. Gene 403: 29-38.

[180] Dunse KM, Anderson MA (2011) Towards the Next Generation of Pest Resistant Plants. ISB News report, Virginia Polytechnic Institute and State University June 2011.

[181] Johnston KS, Lee MJ, Gatehouse JA, Anstee JH (1991) The partial purification and characterisation of serine protease activity in midgut of larval Helicoverpa armigera. Insect Biochem 21: 389-397.

[182] Broadway RM (1995) Are insects resistant to plant proteinase inhibitors? J Insect Physiol 41: 107-116.

[183] Bown DP, Wilkinson HS, Gatehouse JA (1997) Differentially Regulated InhibitorSensitive and Insensitive Protease Genes from the Phytophagus Insect Pest, Helicoverpa armigera, are members of Complex Multigene Families. Insect Biochem Mol Biol 27: 625638.

[184] Markwick NP, Laing WA, Christeller JT, McHenry JZ, Newton MR (1998) Overproduction of Digestive Enzymes Compensates for Inhibitory Effects of Protease and -Amylase Inhibitors Fed to Three Species of Leafrollers (Lepidoptera: Tortricidae). J Econ Entomol 91: 1265-1276.

[185] Zhu-Salzman K, Koiwa H, Salzman RA, Shade RE, Ahn JE (2003) Cowpea bruchid Callosobruchus maculatus uses a three-component strategy to overcome a plant defensive cysteine protease inhibitor. Insect Mol Biol 12: 135-145.

[186] Broadway RM, Duffey SS (1986) Plant proteinase inhibitors: mechanism of action and effect on the growth and digestive physiology of larval Heliothis zea and Spodoptera exiqua. J Insect Physiol 32: 827-833.

[187] De Leo F, Bonade-Bottino MA, Ceci LR, Gallerani R, Jouanin L (1998) Opposite effects on Spodoptera littoralis larvae of high expression level of a trypsin proteinase inhibitor in transgenic plants. Plant Physiol 118: 997-1004.

[188] Alvarez-Alfageme F, Maharramov J, Carrillo L, Vandenabeele S, Vercammen D, Van Breusegem F, Smagghe G (2011) Potential use of a serpin from Arabidopsis for pest control. PLoS One 6: e20278.

[189] Altpeter F, Diaz I, McAuslane H, Gaddour K, Carbonero P, Vasil IK (1999) Increased insect resistance in transgenic wheat stably expressing trypsin inhibitor CMe. Mol Breed 5: 53-63.

[190] Lara P, Ortego F, Gonzalez-Hidalgo E, Castanera P, Carbonero P, Diaz I (2000) Adaptation of Spodoptera exigua (Lepidoptera: Noctuidae) to barley trypsin inhibitor BTI-CMe expressed in transgenic tobacco. Transgenic Res 9: 169-178.

[191] Christy LA, Arvinth S, Saravanakumar M, Kanchana M, Mukunthan N, Srikanth J, Thomas G, Subramonian N (2009) Engineering sugarcane cultivars with bovine 
pancreatic trypsin inhibitor (aprotinin) gene for protection against top borer (Scirpophaga excerptalis Walker). Plant Cell Rep 28: 175-184.

[192] Christeller JT, Burgess EPJ, Mett V, Gatehouse HS, Markwick NP, Murray C, Malone LA, Wright MA, Philip BA, Watt D, Gatehouse LN, Lovei GL, Shannon AL, Phung MM, Watson LM, Laing WA (2002) The expression of a mammalian proteinase inhibitor, bovine spleen trypsin inhibitor in tobacco and its effects on Helicoverpa armigera larvae. Transgenic Res 11: 161-173.

[193] Hoffmann MP, Zalom FG, Wilson LT, Smilanick JM, Malyj LD, Kiser J, Hilder VA, Barnes WM (1992) Field evaluation of transgenic tobacco containing genes encoding Bacillus thuringiensis d-endotoxin or cowpea trypsin inhibitor: efficacy against Helicoverpa zea (Lepidoptera: Noctuidae). J Econ Entomol 85: 2516-2522.

[194] Sane V, Nath P, Aminuddin, Sane P (1997) Development of insect-resistant transgenic plants using plant genes: Expression of cowpea trypsin inhibitor in transgenic tobacco plants. Curr Sci 72: 741-747.

[195] Wu Y, Llewellyn D, Mathews A, Dennis ES (1997) Adaptation of Helicoverpa armigera (Lepidoptera: Noctuidae) to a proteinase inhibitor expressed in transgenic tobacco. Mol Breed 3: 371-380.

[196] De Leo F, Gallerani R (2002) The mustard trypsin inhibitor 2 affects the fertility of Spodoptera littoralis larvae fed on transgenic plants. Insect Biochem Mol Biol 32: 489-496.

[197] Heath RL, McDonald G, Christeller JT, Lee M, Bateman K, West J, Van Heeswijck R, Anderson MA (1997) Proteinase inhibitors from Nicotiana alata enhance plant resistance to insect pests. J Insect Physiol 43: 833-842.

[198] Charity JA, Anderson MA, Bittisnich DJ, Whitecross M, Higgins TJV (1999) Transgenic tobacco and peas expressing a proteinase inhibitor from Nicotiana alata have increased insect resistance. Mol Breed 5: 357-365.

[199] Dunse KM, Stevens JA, Lay FT, Gaspar YM, Heath RL, Anderson MA (2010) Coexpression of potato type I and II proteinase inhibitors gives cotton plants protection against insect damage in the field. Proc Natl Acad Sci U S A 107: 15011-15015.

[200] Johnson R, Narvaez J, An G, Ryan C (1989) Expression of proteinase inhibitors I and II in transgenic tobacco plants: effects on natural defense against Manduca sexta larvae. Proc Natl Acad Sci U S A 86: 9871-9875.

[201] McManus MT, White DWR, McGregor PG (1994) Accumulation of a chymotrypsin inhibitor in transgenic tobacco can affect the growth of insect pests. Transgenic Res 3: 50-58.

[202] Jongsma MA, Bakker PL, Peters J, Bosch D, Stiekema WJ (1995) Adaptation of Spodoptera exigua larvae to plant proteinase inhibitors by induction of gut proteinase activity insensitive to inhibition. Proc Natl Acad Sci U S A 92: 8041-8045.

[203] Winterer J, Bergelson J (2001) Diamondback moth compensatory consumption of protease inhibitor-transformed plants. Mol Ecol 10: 1069-1074.

[204] Abdeen A, Virgós A, Olivella E, Villanueva J, Avilés X, Gabarra R, Prat S (2005) Multiple insect resistance in transgenic tomato plants over-expressing two families of plant proteinase inhibitors. Plant Mol Biol 57: 189-202. 
[205] Luo M, Wang Z, Li H, Xia KF, Cai Y, Xu ZF (2009) Overexpression of a Weed (Solanum americanum) Proteinase Inhibitor in Transgenic Tobacco Results in Increased Glandular Trichome Density and Enhanced Resistance to Helicoverpa armigera and Spodoptera litura. Int J Mol Sci 10: 1896-1910.

[206] Confalonieri M, Allegro G, Balestrazzi A, Fogher C, Delledonne M (1998) Regeneration of Populus Nigra Transgenic Plants Expressing a Kunitz Proteinase Inhibitor (Kti3) Gene. Mol Breed 4: 137-145.

[207] McManus M, Burgess EPJ, Philip B, Watson L, Laing WA, Voisey C, White D (1999) Expression of the soybean (Kunitz) trypsin inhibitor in transgenic tobacco: Effects on larval development of Spodoptera litura. Transgenic Res 8: 383-395.

[208] Nandi AK, Basu D, Das S, Sen SK (1999) High level expression of soybean trypsin inhibitor gene in transgenic tobacco plants failed to confer resistance against damage caused by Helicoverpa armigera. J Biosci (Bangalore) 24: 445-452.

[209] Marchetti S, Delledonne M, Fogher C, Chiaba C, F C, Savazzini F, Giorgadno A (2000) Soybean Kunitz, C-II and PI-IV inhibitor genes confer different levels of insect resistnace to tobacco and potato transgenic plants. Theor Appl Genet 101: 519-526.

[210] Falco MC, Silva-Filho MC (2003) Expression of soybean proteinase inhibitors in transgenic sugarcane plants: effects on natural defense against Diatraea saccharalis. Plant Physiol Biochem 41: 761-766.

[211] Yeh KW, Lin MI, Tuan SJ, Chen YM, Lin CY, Kao SS (1997) Sweet potato (Ipomoea batatas) trypsin inhibitors expressed in transgenic tobacco plants confer resistance against Spodoptera litura. Plant Cell Rep 16: 696-699.

[212] Senthilkumar R, Cheng CP, Yeh KW (2010) Genetically pyramiding protease-inhibitor genes for dual broad-spectrum resistance against insect and phytopathogens in transgenic tobacco. Plant Biotechnol J 8: 65-75.

[213] Liu HB, Guo X, Naeem MS, Liu D, Xu L, Zhang WF, Tang GX, Zhou WJ (2011) Transgenic Brassica napus L. lines carrying a two gene construct demonstrate enhanced resistance against Plutella xylostella and Sclerotinia sclerotiorum. Plant Cell Tiss Org Cult 106: 143-151.

[214] Jongsma MA, Bolter C (1997) The adaptation of insects to plant protease inhibitors. J Insect Physiol 43: 885-895.

[215] Jouanin L, Bonade-Bottino M, Girard C, Morrot G, Giband M (1998) Transgenic plants for insect resistance. Plant Sci 131: 1-11.

[216] Girard C, Le Metayer M, Bonade-Bottino M, Pham-Delegue M-H, Jouanin L (1998) High level of resistance to proteinase inhibitors may be conferred by proteolytic cleavage in beetle larvae. Insect Biochem Mol Biol 28: 229-237.

[217] Paulillo LC, Lopes AR, Cristofoletti PT, Parra JR, Terra WR, Silva-Filho MC (2000) Changes in midgut endopeptidase activity of Spodoptera frugiperda (Lepidoptera: Noctuidae) are responsible for adaptation to soybean proteinase inhibitors. J Econ Entomol 93: 892-896.

[218] Gatehouse LN, Shannon AL, Burgess EP, Christeller JT (1997) Characterization of major midgut proteinase cDNAs from Helicoverpa armigera larvae and changes in gene 
expression in response to four proteinase inhibitors in the diet. Insect Biochem Mol Biol 27: 929-944.

[219] Giri AP, Harsulkar AM, Deshpande VV, Sainani MN, Gupta VS, Ranjekar PK (1998) Chickpea Defensive Proteinase Inhibitors Can Be Inactivated by Podborer Gut Proteinases. Plant Physiol 116: 393-401.

[220] Telang MA, Giri AP, Sainani MN, Gupta VS (2005) Characterization of two midgut proteinases of Helicoverpa armigera and their interaction with proteinase inhibitors. J Insect Physiol 51: 513-522.

[221] Michaud D, Nguyen-Quoc B, Vrain TC, Fong D, Yelle S (1996) Response of digestive cysteine proteinases from the Colorado potato beetle (Leptinotarsa decemlineata) and the black vine weevil (Otiorynchus sulcatus) to a recombinant form of human stefin A. Arch Insect Biochem Physiol 31: 451-464.

[222] Volpicella M, Ceci LR, Cordewener J, America T, Gallerani R, Bode W, Jongsma MA, Beekwilder J (2003) Properties of purified gut trypsin from Helicoverpa zea, adapted to proteinase inhibitors. Eur J Biochem 270: 10-19.

[223] Bown DP, Wilkinson HS, Gatehouse JA (2004) Regulation of expression of genes encoding digestive proteases in the gut of a polyphagous lepidopteran larva in response to dietary protease inhibitors. Physiol Entomol 29: 278-290.

[224] Chougule NP, Giri AP, Sainani MN, Gupta VS (2005) Gene expression patterns of Helicoverpa armigera gut proteases. Insect Biochem Mol Biol 35: 355-367.

[225] Girard C, Lemetayer M, Zaccomer B, Bartlet E, Williams I, Bonadebottino M, Phamdelegue MH, Jouanin L (1998) Growth stimulation of beetle larvae reared on a transgenic oilseed rape expressing a cysteine proteinase inhibitor. J Insect Physiol 44: 263-270.

[226] Cloutier C, Fournier M, Jean C, Yelle S, Michaud D (1999) Growth compensation and faster development of Colorado potato beetle (Coleoptera : Chrysomelidae) feeding on potato foliage expressing oryzacystatin I. Arch Insect Biochem Physiol 40: 69-79.

[227] Broadway RM (1997) Dietary regulation of serine proteinases that are resistant to serine proteinase inhibitors. J Insect Physiol 43: 855-874.

[228] Markwick NP, Laing WA, Christeller JT, McHenry JZ, Newton MR (1998) Overproduction of Digestive Enzymes Compensates for Inhibitory Effects of Protease and -Amylase Inhibitors Fed to Three Species of Leafrollers (Lepidoptera: Tortricidae). J Econ Entomol 91: 1265-1276.

[229] Mazumdar-Leighton S, Broadway RM (2001) Identification of six chymotrypsin cDNAs from larval midguts of Helicoverpa zea and Agrotis ipsilon feeding on the soybean (Kunitz) trypsin inhibitor. Insect Biochem Mol Biol 31: 633-644.

[230] Mazumdar-Leighton S, Ragahavendra Babu C, Bennett J (2000) Identification of novel serine proteinase gene transcripts in the midguts of two tropical insect pests, Scirpophaga incertulas (Wk.) and Helicoverpa armigera $(\mathrm{Hb}$.). Insect Biochem Mol Biol 30: 57-68.

[231] Mazumdar-Leighton S, Broadway RM (2001) Transcriptional induction of diverse midgut trypsins in larval Agrotis ipsilon and Helicoverpa zea feeding on the soybean trypsin inhibitor. Insect Biochem Mol Biol 31: 645-657. 
[232] Atkinson AH, Heath RL, Simpson RJ, Clarke AE, Anderson MA (1993) Proteinase Inhibitors in Nicotiana alata Stigmas Are Derived from a Precursor Protein Which Is Processed into Five Homologous Inhibitors. Plant Cell 5: 203-213.

[233] Miller EA, Lee MC, Anderson MA (1999) Identification and characterization of a prevacuolar compartment in stigmas of Nicotiana alata. Plant Cell 11: 1499-1508.

[234] Nielsen KJ, Hill JM, Anderson MA, Craik DJ (1996) Synthesis and structure determination by NMR of a putative vacuolar targeting peptide and model of a proteinase inhibitor from Nicotiana alata. Biochemistry 35: 369-378.

[235] Scanlon MJ, Lee MC, Anderson MA, Craik DJ (1999) Structure of a putative ancestral protein encoded by a single sequence repeat from a multidomain proteinase inhibitor gene from Nicotiana alata. Structure 7: 793-802.

[236] Nielsen KJ, Heath RL, Anderson MA, Craik DJ (1994) The three-dimensional solution structure by ${ }^{1} \mathrm{H}$ NMR of a $6-\mathrm{kDa}$ proteinase inhibitor isolated from the stigma of Nicotiana alata. J Mol Biol 242: 231-243.

[237] Lee MC, Scanlon MJ, Craik DJ, Anderson MA (1999) A novel two-chain proteinase inhibitor generated by circularization of a multidomain precursor protein. Nat Struct Biol 6: 526-530.

[238] Nielsen KJ, Heath RL, Anderson MA, Craik DJ (1995) Structures of a series of 6-kDa trypsin inhibitors isolated from the stigma of Nicotiana alata. Biochemistry 34: 1430414311.

[239] Heath RL, Barton PA, Simpson RJ, Reid GE, Lim G, Anderson MA (1995) Characterization of the protease processing sites in a multidomain proteinase inhibitor precursor from Nicotiana alata. Eur J Biochem 230: 250-257.

[240] Lee MCS, Scanlon MJ, Craik DJ, Anderson MA (1999) A novel two-chain proteinase inhibitor generated by circularization of a multidomain precursor protein. Nat Struct Mol Biol 6: 526-530.

[241] Atkinson A, Lind J, Clarke A, Anderson M (1994) Molecular and structural features of the pistil of Nicotiana alata. Biochem Soc Symp. pp. 15.

[242] Harsulkar AM, Giri AP, Patankar AG, Gupta VS, Sainani MN, Ranjekar PK, Deshpande VV (1999) Successive use of non-host plant proteinase inhibitors required for effective inhibition of Helicoverpa armigera gut proteinases and larval growth. Plant Physiol 121: 497-506.

[243] Murdock LL, Shade RE (2002) Lectins and protease inhibitors as plant defenses against insects. J Agric Food Chem 50: 6605-6611.

[244] Chiche L, Heitz A, Padilla A, Lenguyen D, Castro B (1993) Solution Conformation of a Synthetic Bis-Headed Inhibitor of Trypsin and Carboxypeptidase A: New Structural Alignment between the Squash Inhibitors and the Potato Carboxypeptidase Inhibitor. Protein Eng 6: 675-682.

[245] Urwin PE, McPherson MJ, Atkinson HJ (1998) Enhanced transgenic plant resistance to nematodes by dual proteinase inhibitor constructs. Planta 204: 472-479.

[246] Oppert B, Morgan TD, Hartzer K, Kramer KJ (2005) Compensatory proteolytic responses to dietary proteinase inhibitors in the red flour beetle, Tribolium castaneum (Coleoptera : Tenebrionidae). Comp Biochem Physiol, C: Toxicol Pharmacol 140: 53-58. 
[247] Fan X, Shi X, Zhao J, Zhao R, Fan Y (1999) Insecticidal activity of transgenic tobacco plants expressing both Bt and CpTI genes on cotton bollworm (Helicoverpa armigera). Chin J Biotechnol 15: 1.

[248] MacIntosh SC, Kishore GM, Perlak FJ, Marrone PG, Stone TB, Sims SR, Fuchs RL (1990) Potentiation of Bacillus thuringiensis insecticidal activity by serine protease inhibitors. J Agric Food Chem 38: 1145-1152.

[249] Pannetier C, Giband M, Couzi P, Le Tan V, Mazier M, Tourneur J, Hau B (1997) Introduction of new traits into cotton through genetic engineering: insect resistance as example. Euphytica 96: 163-166.

[250] Markwick NP, Reid SJ, Liang WA, Christeller JT (1995) Effects of dietary protein and protease inhibitors on codling moth (Lepidoptera: Tortricidae). J Econ Entomol 88: 3339.

[251] Tabashnik BE, Gassmann AJ, Crowder DW, Carriere Y (2008) Insect resistance to Bt crops: evidence versus theory. Nat Biotech 26: 199-202. 